\title{
Detrital zircon geochronology of the Cretaceous succession from the Iberian Atlantic Margin: palaeogeographic implications
}

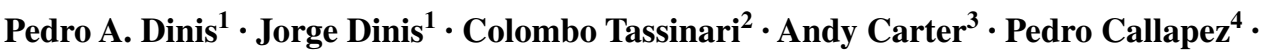 \\ Manuel Morais ${ }^{4}$
}

Received: 22 November 2014 / Accepted: 20 June 2015 / Published online: 21 July 2015

(C) Springer-Verlag Berlin Heidelberg 2015

\begin{abstract}
Detrital zircon U-Pb data performed on eight Cretaceous sandstone samples (819 age isotopic results) from the Lusitanian basin (west Portugal) constrain the history of uplift and palaeodrainage of western Iberia following break-up of Pangaea and opening of the North Atlantic Ocean. We examined the links between shifts in provenance and known basinwide unconformities dated to the late Berriasian, Barremian, late Aptian and Cenomanian-Turonian. The detrital zircon record of sedimentary rocks with wider supplying areas is relatively homogenous, being characterized by a clear predominance of late Palaeozoic ages (c. 375-275 Ma) together with variable proportions of ages in the range c. 800-460 Ma. These two groups of ages are diagnostic of sources within the Variscan Iberian Massif. A few samples also reveal significant amounts of middle Palaeozoic (c. 420-385 Ma) and late Mesoproterozoic to early Neoproterozoic (c. 1.2-0.9 Ga) zircon, which are almost absent in the basement to the east of the Lusitanian basin, but are common in terranes with a Laurussia affinity found
\end{abstract}

Electronic supplementary material The online version of this article (doi:10.1007/s00531-015-1221-z) contains supplementary material, which is available to authorized users.

Pedro A. Dinis

pdinis@dct.uc.pt

1 IMAR - Marine and Environmental Research Centre, Department of Earth Sciences, University of Coimbra, Coimbra, Portugal

2 Instituto de Geociências, Universidade de São Paulo/CPGeo, São Paulo, Brazil

3 Department of Earth and Planetary Sciences Birkbeck, University of London, London, UK

4 Centre for Geophysics, University of Coimbra, Coimbra, Portugal in NW Iberia and the conjugate margin (Newfoundland). The Barremian unconformity marks a sudden rise in the proportion of c. 375-275 Ma zircon ages accompanied by a decrease in the abundance of the c. 420-385 Ma and c. 1.2-0.9 Ga ages. This shift in the zircon signature, which is contemporaneous with the separation of the Galicia Bank from Flemish Cap, reflects increased denudation of Variscan crystalline rocks and a reduction in source material from NW Iberia and adjoining areas. The late Aptian unconformity, which represents the largest hiatus in the sedimentary record, is reflected by a shift in late Palaeozoic peak ages from c. 330-310 Ma (widespread in Iberia) to c. 310-290 Ma (more frequent in N Iberia). It is considered that this shift in the age spectra resulted from a westward migration of catchment areas following major uplift in northern Iberia and some transport southward from the Bay of Biscay under the influence of a well-established Atlantic circulation.

Keywords Provenance - Detrital zircon geochronology · Lusitanian basin · Pangea break-up · Unconformity

\section{Introduction}

Break-up of Pangaea and the opening of the North Atlantic Ocean initiated the formation of a series of basins along what is now the eastern and western margin of the Atlantic Ocean. The Iberian Lusitanian basin emerged from this process, while on its North American conjugate margin, in Newfoundland, several Grand Banks basins formed, including the Jeanne d'Arc, Carson, Horseshoe and Whale basins (Fig. 1). The sedimentary fill of these basins records a history of regional basement erosion that has a composition and age structure dictated by a succession of events 


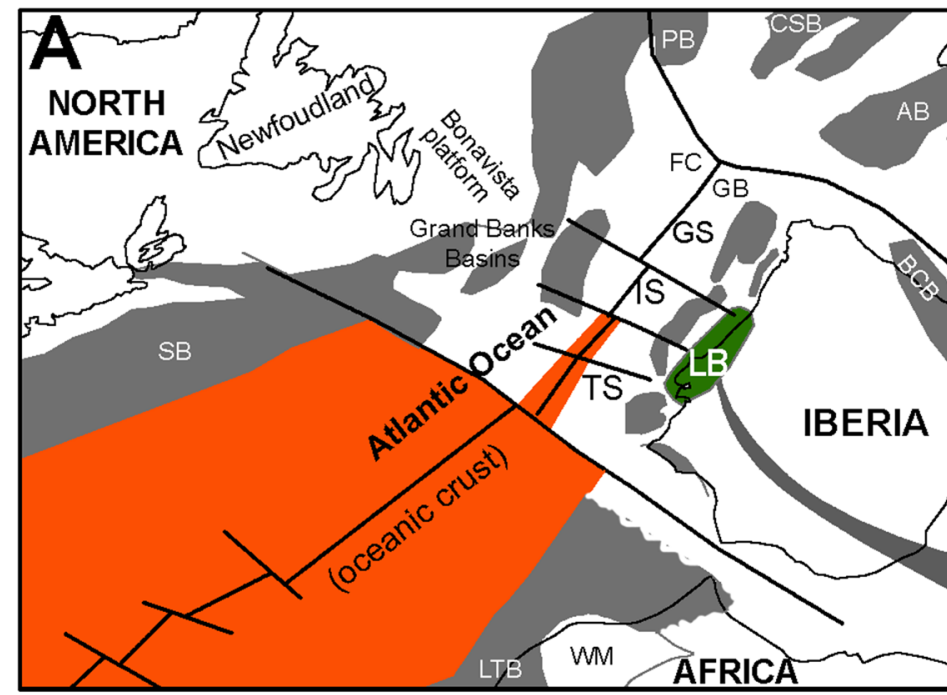

9

C
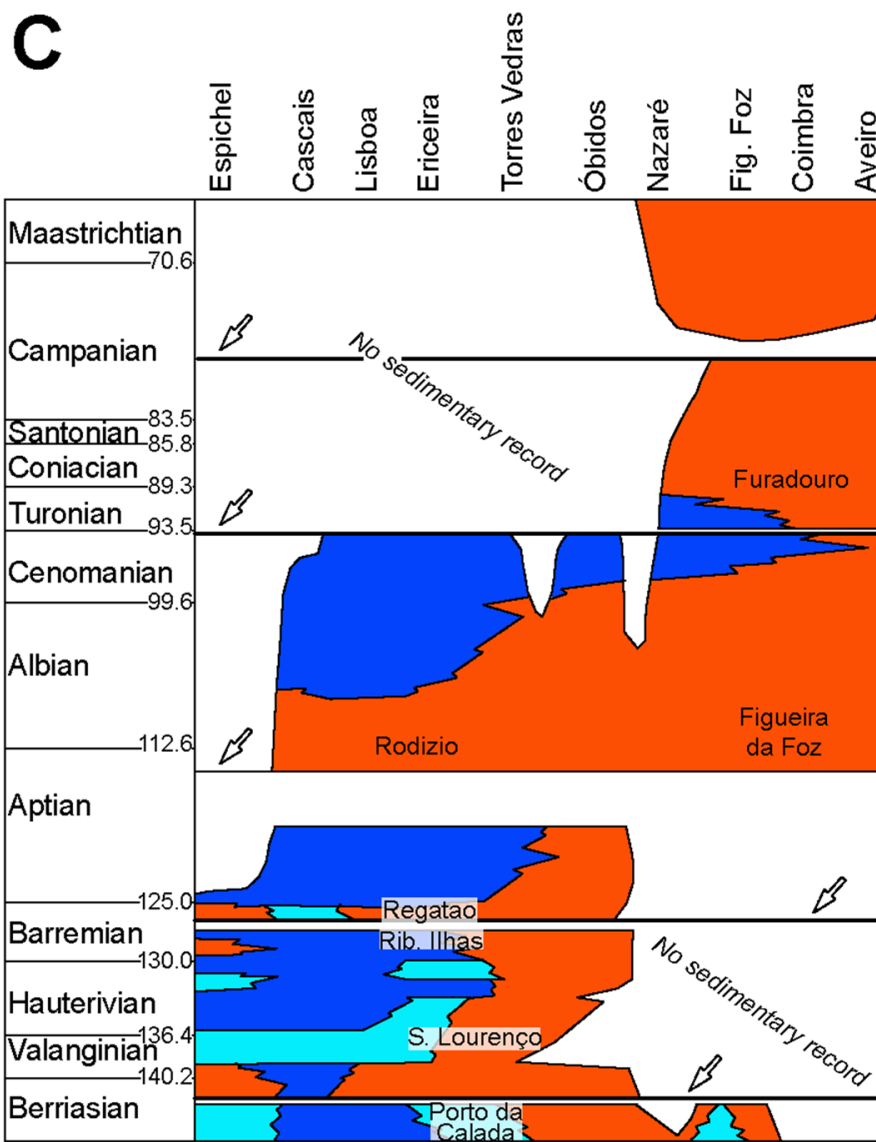

Outer and inner

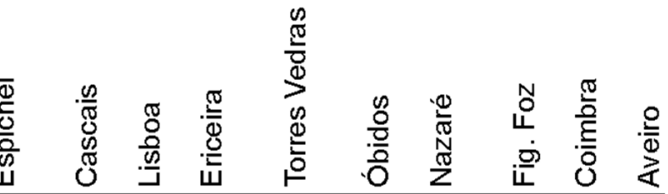

.
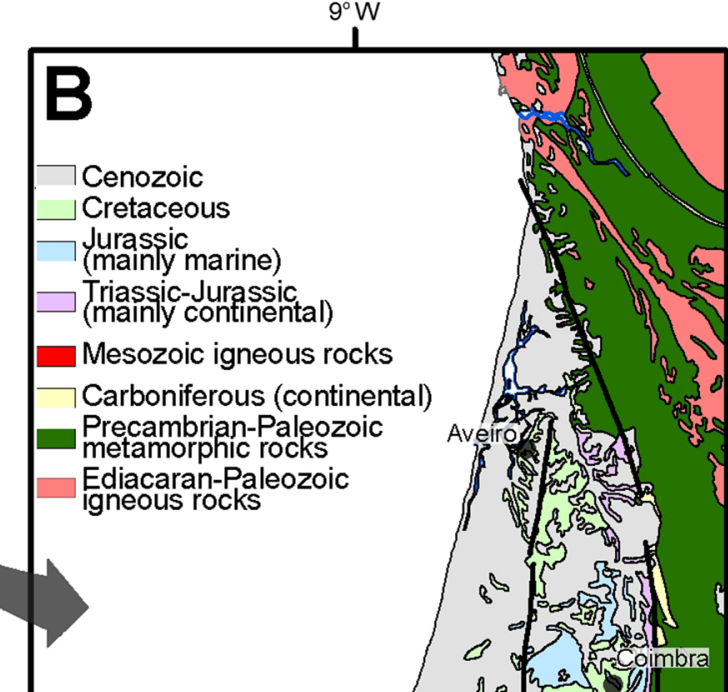

Ediacaran-Paleozoic

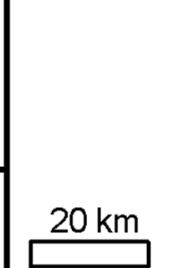

$200^{\circ} \mathrm{km}$
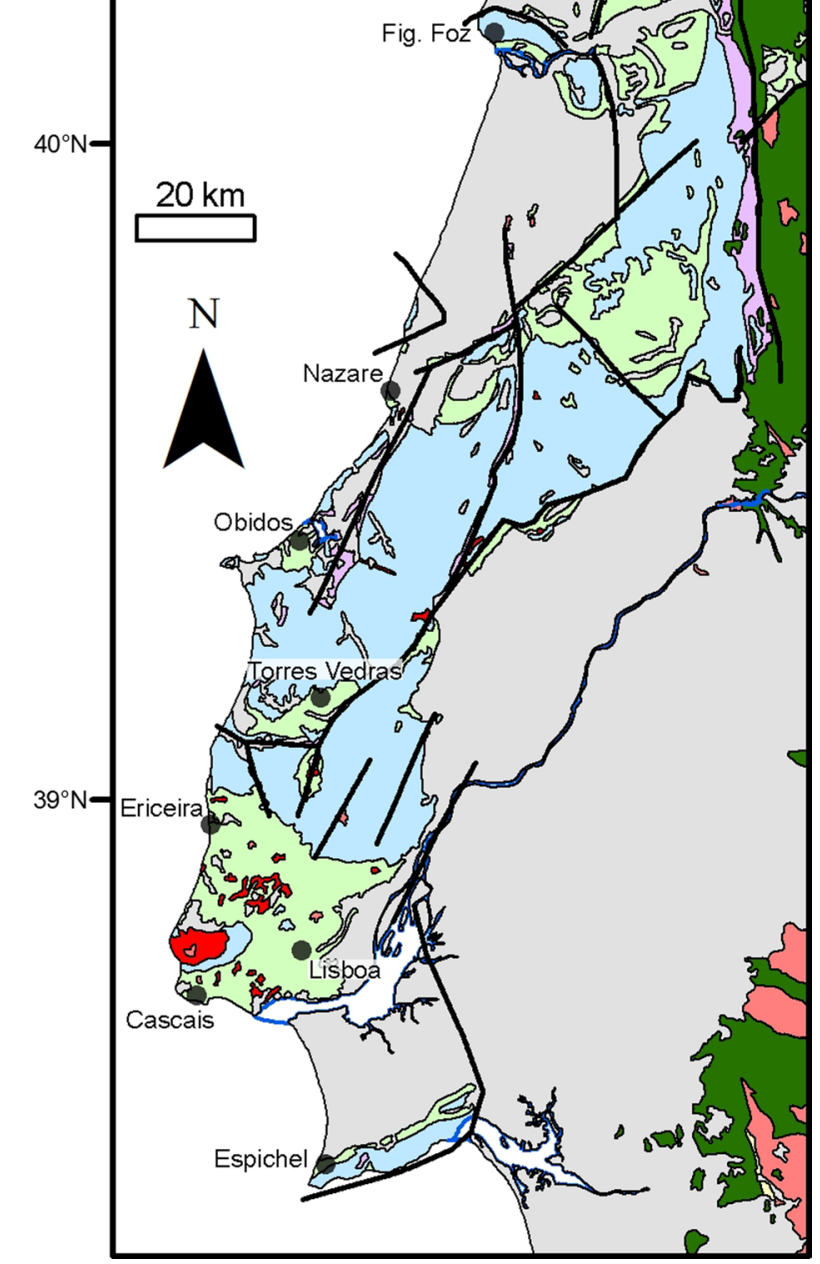

Fig. 1 Geological and stratigraphic framework of the studied deposits. a The Lusitanian basin and its context within northern Atlantic during Cretaceous opening. Position of the continental areas from Sibuet et al. (2012). b Geological sketch of central west Iberian margin. c Stratigraphic scheme of the Cretaceous units from western Portugal based on Dinis et al. (2008). Sampled units are indicated. Bas-

inwide unconformities represented by bold horizontal lines signed with arrows. GS Galicia Sector, IS Iberian Sector, TS Tagus Sector, $G B$ Galicia Bank, $F C$ Flemish Cap, $S B$ Scotian basin, $P B$ Porcupine basin, $C S B$ Celtic Sea basin, $A B$ Armorican and Western Approaches basins, $B C B$ Basque-Cantabrian basin, WM Western Meseta, LTB Laayoune-Tarfaya basin 
that involved the amalgamation of the Laurussia continent and subsequent collision with Gondwana. Ganderia, Avalonia and the Meguma peri-Gondwana terranes drifted away from the Gondwana margin and collided with Laurentia between the late Silurian and late Devonian (Murphy et al. 2011). Collision between Gondwana and Laurussia during the Carboniferous led to the final amalgamation of Pangea (Variscan-Alleghanian orogenies; see synthesis in Simancas et al. 2005; Martínez Catalán et al. 2007; Ribeiro et al. 2007; Murphy et al. 2011). From the late Triassic to early Cretaceous, the region was affected by the rifting between Newfoundland and Iberia, associated with Atlantic Ocean opening. The extension was responsible for the development of sets of oceanward dipping extensional faults that converged into a major detachment zone, regional tilting, rotational movements and the formation of isolated halfgraben basins (Tankard and Welsink 1987; Boillot and Froitzheim 2001; Alves et al. 2006; Afilhado et al. 2008).

The Cretaceous sedimentary rocks of the north-west Atlantic basins have been extensively studied, making use of numerous tools to establish sediment provenance, such that there is a good understanding of the sedimentary routing systems throughout break-up (e.g. Piper et al. 2007, 2012; Hiscott et al. 2008; Pe-Piper et al. 2008; Lowe et al. 2011; Reynolds et al. 2010; Tsikouras et al. 2011). In the Lusitanian basin, which has a well-established stratigraphic framework tied to precise biostratigraphic dating (see Dinis et al. 2008 and references herein), the Cretaceous succession comprises alluvial, marginal marine and carbonate platform sequences that can be related to major eustatic sea-level changes and uplift events on the Iberian margin. The sequence contains several important basinwide unconformities that have been linked to diachronous rifting, mantle exhumation and seafloor spreading processes that are progressively younger to the north (Whitmarsh et al. 1996; Whitmarsh and Wallace 2001; Rey 2006; Dinis et al. 2008; Alves et al. 2009). However, it is not well known if and to what extent these unconformities are linked to changes in the sediment delivery systems and onshore denudation. To address this, we conducted a detrital zircon provenance study.

Detrital zircon geochronology has been successfully used to constrain provenance and sediment routing for several north-west Atlantic basins (Lowe et al. 2011; Piper et al. 2012), but no comparable systematic research has been conducted on the west Iberian Atlantic basins. Using detrital zircon geochronology performed on samples collected from strategic locations in the Lusitanian basin, we provide new constraints on the history of regional uplift, palaeodrainage and controls on sediment flux. We test whether the previously recognized unconformities are marked by shifts in sediment provenance, focusing on contributions from Palaeozoic basement units as well as the exhumation of younger crystalline rocks as this information may also help refine palaeogeographic models for the evolution of the north-east Atlantic.

\section{Geological setting and stratigraphy}

Among the basins on the Iberian Atlantic margin, the Lusitanian basin stands out by its elongated shape parallel to the Atlantic coast (Wilson 1979; Pinheiro et al. 1996). The Central Iberian Zone, to the North, and Ossa Morena Zone, to the South, from western locations of the Iberian Massif (Lotze 1945), constitute the basement of the Lusitanian basin. In NW Iberia, the Central Iberian Zone is in contact with the structurally complex Galicia Trás-os-Montes Zone that comprises allochthonous units partially associated with the closure of the Rheic Ocean (Ribeiro et al. 1990, 2007; Dallmeyer et al. 1991; Marques et al. 1996; Martínez Catalán et al. 2007). The Central Iberian Zone is formed mainly by late Neoproterozoic to Palaeozoic metasedimentary units along with diverse Carboniferous-Permian Variscan to post-Variscan granitoids (e.g. Pinto et al. 1987; Fernández-Suárez et al. 2000; Gutiérrez-Alonso et al. 2011) and Ediacaran to Cambro-Ordovician pre-Variscan intrusive and extrusive rocks (e.g. Pinto et al. 1987; Solá et al. 2008; Díez Montes et al. 2010; Talavera et al. 2013). The Ossa Morena Zone is subdivided into distinct domains on the basis of lithostratigraphy, deformation and metamorphism (Apalategui et al. 1990; Eguíluz et al. 2000). In association with its complex geodynamic history, several thermal episodes are recognized in this zone, including the Neoproterozoic-Cambrian and Cambro-Ordovician (e.g. Eguíluz et al. 2000; Galindo and Casquet 2004; Linnemann et al. 2008) and the subsequent, late Palaeozoic, Variscan-related magmatic stages (e.g. Pinto et al. 1987; Eguíluz et al. 2000; Jesus et al. 2007).

Seafloor spreading began after a succession of rifting phases that climaxed during the late Jurassic (Wilson et al. 1989; Leinfelder and Wilson 1998). In west Iberia, the late Jurassic to Cretaceous Atlantic Ocean opening was diachronous, progressing northwards, punctuated by discrete events along different sectors separated by structural lineaments (Whitmarsh et al. 1996; Pinheiro et al. 1996; Alves et al. 2003, 2009; Rey et al. 2006). The Tagus, Iberia and Galicia sectors, defended by Rey (2006) and Dinis et al. (2008), are considered in this study (Fig. 1a). The Cretaceous succession ranges from the lowermost Berriasian to the upper Campanian-Maastrichtian (Fig. 1c). Based on the onshore Cretaceous stratigraphy, a southern and a northern domain can be recognized, each with characteristic facies architecture, age and subsidence history (Stapel et al. 1996). The boundary between these two domains is roughly coincident with a tectonic axis known as the 
Caldas da Rainha-Nazaré-Pombal; south of this axis the stratigraphic succession is older, dominated by the deposition of Berriasian to Cenomanian sediments, while to the north, it shows a thick Aptian to Maastrichtian infill (Rey et al. 2006; Dinis et al. 2008).

Within the Cretaceous succession, five major unconformities and facies turnovers have been recognized (Dinis et al. 2008 and references herein). The first unconformity is late Berriasian, preceding the formation of oceanic crust in the Tagus sector (Pinheiro et al. 1996). It is well recognized in the southern parts of the Lusitanian basin where coarse alluvial sediments overlie upper Jurassic and Berriasian platform carbonates (Rey 2006) and was followed by an intra-Barremian rupture that has a strongly regressive signal, marked by retreat of carbonate sedimentation and progradation of braided alluvial systems (Rey 2006; Rey et al. 2006). This episode should be related to the onset of seafloor spreading along the Iberian segment of the Atlantic margin (Whitmarsh and Wallace 2001) that followed early alkaline or transitional magmatism in the North Atlantic (Jagoutz et al. 2007; Miranda et al. 2009). The third major break in sedimentation is late Aptian, matching the beginning of seafloor spreading in the Galician sector (Schärer et al. 2000), final separation of subcontinental mantle lithosphere (Tucholke et al. 2007) and a second phase of alkaline magmatism (Jagoutz et al. 2007). This unconformity also marks the beginning of post-rift sedimentation, a process that started with widespread deposition of coarse siliciclastic sediments (Cunha and Reis 1995; Dinis and Trincão 1995; Dinis et al. 2002, 2008) and culminated in the Albian and Cenomanian with the formation of the west Portuguese carbonate platform (Soares 1980; Berthou 1984a, b; Callapez 2008). A further sedimentary rupture was contemporaneous with the Cenomanian-Turonian transition, when the southern domain of the onshore margin was significantly uplifted and new readjustments occurred on the Iberian block (Dinis et al. 2008; Barroso-Barcenilla et al. 2011; Segura et al. 2014). This rupture broadly coincides with the onset of an alkaline pulse in Lisbon region (Miranda et al. 2009). Finally, there is evidence of a large unconformity of early Campanian age in the northern locations of the coastal margin.

In the Cascais-Ericeira region, the Berriasian-Aptian interval is represented by nine formations (including the São Lourenço, Ribeira d'Ilhas and Regatão Fms.; Rey 1993, 2006). The succession consists of three second-order depositional cycles ranging from the uppermost Jurassic to the upper Aptian, with transgressive maximums recorded at the lower Hauterivian and lower Aptian, and regressive boundaries matching with the upper Berriasian, Barremian and upper Aptian unconformities (Rey et al. 2003; Rey 2006). From the upper Aptian onwards, the sedimentary record reveals a substantial enlargement of the area of deposition, with thick alluvial successions associated with prograding braided river systems (Rodízio Fm., Rey 1992; Figueira da Foz Fm., Dinis 2001). From the late-early Albian, a gradual retreat of the alluvial systems occurred in southern parts of the Lusitanian basin, followed by the deposition of marginal marine mixed sediments and innershelf carbonates (Rey 2006). These middle and upper Albian shallow marine units represent the first growth stages of the Albian-Turonian western Portuguese carbonate platform (Berthou 1984b; Callapez 2008). At the end of late Cenomanian, the west Portuguese margin was uplifted, the carbonate platform became temporarily exposed, and the post-Cenomanian series confined mainly to northern locations of the margin (Callapez 2008; Hart et al. 2005). The succession includes littoral plain deposits (Furadouro Fm., Barbosa et al. 1988) that pass westward into carbonate units.

\section{Materials and methods}

\section{Sampled sediments}

To improve understanding of the significance of the major unconformities in the Cretaceous succession, 8 representative samples for detrital zircon geochronology analysis were collected from outcrops in the Ericeira (samples ZPC, ZSLN, ZRIN, ZERI1 and ZERI2), Nazaré (sample ZJUN) and Figueira da Foz-Coimbra (samples ZBUA and ZMFMF) regions (Fig. 2; Supplementary Material 1). In the Ericeira region, samples were from the upper Berriasian (below the late Berriasian unconformity) to upper Aptian or lower Albian (above the late Aptian unconformity). Upper Aptian-lower Albian deposits were also sampled in Nazaré and Figueira da FozCoimbra regions. The Turonian sample is from the Figueira da Foz-Coimbra region. Conglomeratic units immediately above the recognized unconformities were not selected because they probably provide a local signal of sediment supply.

Sample ZPC comes from a coarse-grained sandstone that was taken within the upper part of the upper Jurassic cycle, which is thought to culminate during the Berriasian (Reis et al. 2000), in deltaic deposits of Porto da Calada Fm. (Rey 1993). Sample ZSLN is from a fluvio-deltaic cross-bedded sandstone intercalated with organic-rich mudstone, which belong to the upper Valanginian São Lourenço Fm. (Rey 1993, 2006). Sample ZRIN was collected in a medium- to coarse-grained sandstone with low-angle cross-bedding found between bioclastic carbonate rocks, associated with deposition in inter-tidal setting, from the Barremian Ribeira de Ilhas Fm. (Rey 1993, 2006). Samples ZERI1 and ZERI2 are from fluvio-deltaic, trough cross-bedded, poorly sorted coarse sandstones to fine conglomerates. ZERI1 comes from the top of Regatão Fm. (upper Barremian; Rey 1993, 2006), 
Fig. 2 Schematic stratigraphic sections for the sectors of Ericeira, Nazaré and CoimbraFigueira da Foz with the location of the sampled beds

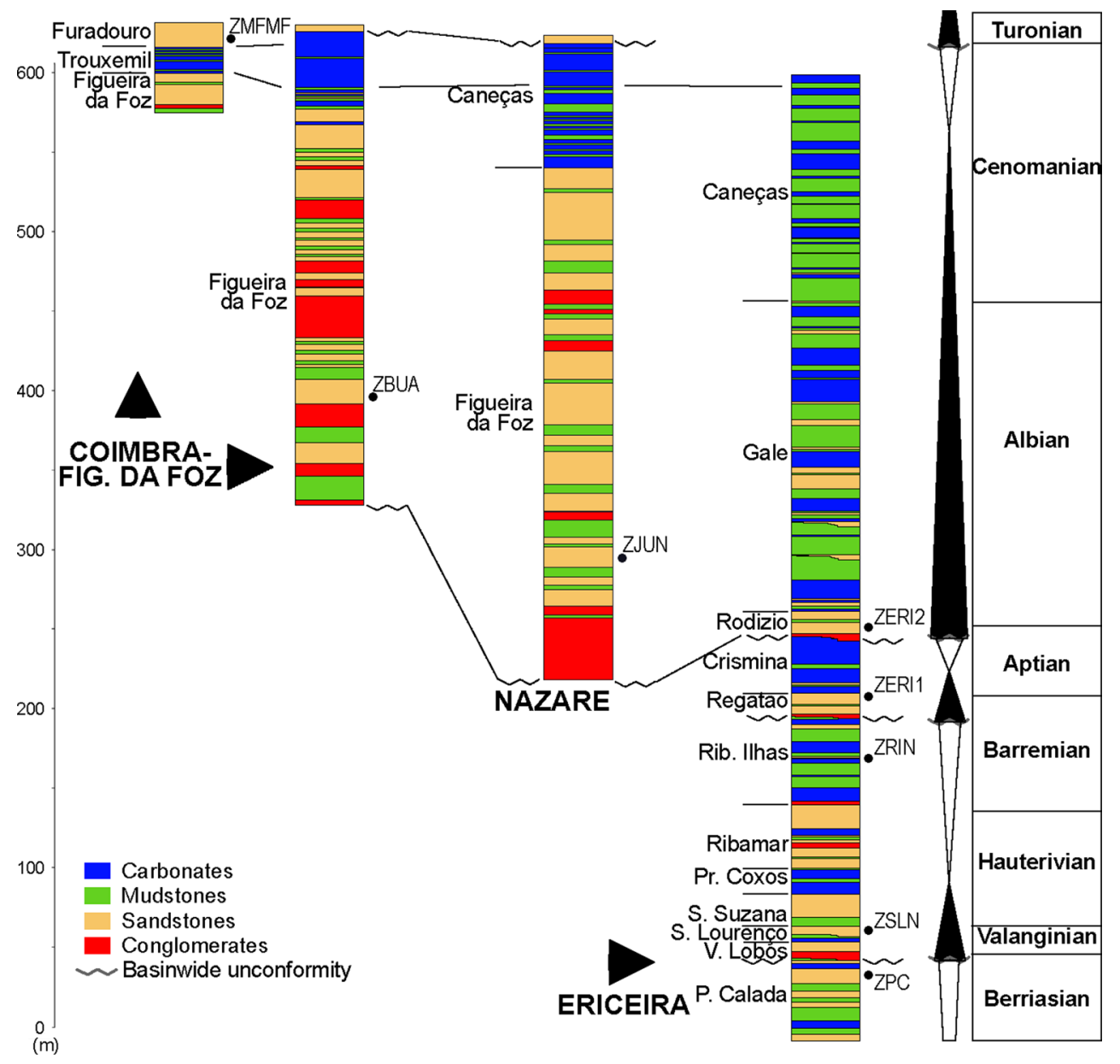

while ZERI2 was collected near the base of Rodízio Fm. (upper Aptian or lower Albian; Rey 2006). Samples ZJUN, from Juncal section, and ZBUA, from Buarcos section, were collected in fluvial deposits at the lower part of Figueira da Foz Fm. (upper Aptian or lower Albian; Dinis 2001) and consist of arkosic pebbly sandstones. Sample ZMFMF was taken west of Coimbra from a nearshore parallel-laminated fine sandstone bed with discrete granule to fine pebble lamina that belong to the Turonian Furadouro Fm. (Barbosa et al. 1988).

\section{Laser ablation ICP-MS analytical procedure}

Separation of zircon grains was carried out at the Earth Sciences Department of University of Coimbra. Samples were manually disintegrated, and the fractions finer than $0.038 \mathrm{~mm}$ and coarser than $0.5 \mathrm{~mm}$ were removed through wet sieving. Heavy liquids (sodium polytungstate and methylene iodide) and a Frantz isodynamic magnetic separator were used to obtain the zircon concentrates. Polished mounts of zircon fractions were imaged with a FEIQUANTA 250 scanning electron microscope equipped with secondary electron and cathodoluminescence at the University of São Paulo.
$\mathrm{U}-\mathrm{Pb}$ and isotope compositions were determined by laser ablation inductively coupled plasma source mass spectrometry (Supplementary Material 1). Analyses were conducted using two facilities. A first set of samples were analysed at the Geochronological Research Center of the University of São Paulo. The analyses were carried out on a Thermo multicollector ICP-MS, Neptune type, coupled to an excimer ArF laser ablation system. Ablation used a frequency of $6 \mathrm{~Hz}$ and an intensity of $6 \mathrm{~mJ}$. Unknowns were bracketed by measurements of the international standard GJ-1 (608.5 \pm 0.4 Ma; Jackson et al. 2004). Raw data were reduced using an in-house spreadsheet and corrected for background, instrumental mass bias drift and common $\mathrm{Pb}$. A second set of samples were measured at University College of London using a New Wave $193 \mathrm{~nm}$ excimer laser ablation system coupled to an Agilent 7700 quadrupole-based ICP-MS. The laser was set up to produce an energy density of ca $2.5 \mathrm{~J} / \mathrm{cm}^{2}$ at a repetition rate of $10 \mathrm{~Hz}$. Repeated measurements of external zircon standard PLESOVIC (TIMS reference age $337.13 \pm 0.37$ Ma; Sláma et al. 2008) and NIST 612 silicate glass (Pearce et al. 1997) were used to correct for instrumental mass bias and depthdependent inter-element fractionation of $\mathrm{Pb}$, Th and $\mathrm{U}$. 
91500 (Wiedenbeck et al. 2004) and Temora (Black et al. 2003) zircon were used as secondary age standards. Realtime data were processed using GLITTER 4.4 data reduction software. For both facilities, analytical uncertainties on the ages take into account the reproducibility of the age standard for each analytical session, which are typically in the range of $2-4 \%$.

Three samples (ZSLN, ZERI1 and ZRIN) were analysed in both laboratories. Based on the similarities of the Kernel density plots (Vermeesch 2012), data from the two laboratories are considered comparable (Supplementary Material 2). Isoplot 3.72 (Ludwig 2008) was used for the calculation and plotting of concordia diagrams. Kernel density plots obtained with the DensityPlotter software (Vermeesch 2012) were adopted to visualize the age distributions and define the most important events of zircon generation. Although a visual comparison can be informative as to the similarity between age spectra of different samples, we quantified their similarity more rigorously using a standard statistical method known as multidimensional scaling (MDS, see Vermeesch 2013). The Gradstein et al. (2004) geological timescale was adopted in the age data description and discussion.

\section{Zircon $\mathrm{U}-\mathrm{Pb}$ isotopic results}

Concordant zircon ages range between 3388 and $169 \mathrm{Ma}$, but the majority of the measurements provided results younger than $800 \mathrm{Ma}$ (c. $85 \%$ ). Data were filtered using standard discordance tests, based on the ratios between ${ }^{206} \mathrm{~Pb} /{ }^{207} \mathrm{~Pb}$ and ${ }^{206} \mathrm{~Pb} /{ }^{238} \mathrm{U}$ ages, with a $10 \%$ cut-off. Additionally, because ${ }^{206} \mathrm{~Pb} /{ }^{207} \mathrm{~Pb}$ ages are unreliable for younger zircon, when the ratios between ${ }^{206} \mathrm{~Pb} /{ }^{238} \mathrm{U}$ and ${ }^{207} \mathrm{~Pb} /{ }^{235} \mathrm{U}$ ages were between 0.95 and 1.05 for zircon younger than $500 \mathrm{Ma}$, these data were also considered concordant. The eight samples presented in this study provided $819 \mathrm{U}-\mathrm{Pb}$ results, out of which 674 are concordant. The number of analyses in each sample is variable (66 in ZBUA; 154 in ZERI1; 80 in ZERI2; 88 in ZJUN; 75 in ZMFMF; 85 in ZPC; 94 in ZRIN; 177 in ZSLN) such that some minor age populations may not have been detected (117 grain ages have a $95 \%$ probability that all source ages were detected, Vermeesch 2004). We report the \% of zircon ages present in the major populations to illustrate the relative abundances of ages in each sample but note that such values are not absolute as they are subject to the influences of rock sample zircon fertility, analytical approaches and variable size data sets (e.g. Moecher and Samson 2006; Hieptas et al. 2011; Lawrence et al. 2011).

Most zircon grains are small sized, euhedral or subhedral, with more or less elongated prisms and pyramids.
Rounded grains are also common. Part of the analysed grains show clear magmatic growth zoning of variable thickness, while others seem to be homogenous or include portions with homogenous and oscillatory zoning. A few grains comprise a distinguishable xenocryst core mantled by younger zircon.

\section{Berriasian (ZPC)}

Of the 85 age determinations from sample ZPC, 68 were concordant. The detrital zircon ages in this sample spread between c. $178 \mathrm{Ma}$ and c. $2764 \mathrm{Ma}$ (Figs. 3, 4). The majority of the concordant zircon ages are middle to late Carboniferous, spanning c. 358-282 Ma (45\%), with a dominant peak at c. $330 \mathrm{Ma}$. The second most common group (39 \%) are Ediacaran to early Devonian ages that range from c. 623 to $395 \mathrm{Ma}$, with dominant peaks at c. $480 \mathrm{Ma}$ and c. 520 Ma. The sample also yields some Permian ages (c. $270 \mathrm{Ma}$ ) and a few lower Neoproterozoic to Archean ages (c. 720-819 Ma, 1.0 Ga and 2.5-2.8 Ga).

\section{Valanginian-lower Barremian (ZSLN and ZRIN)}

Both Valanginian (ZSLN) and lower Barremian (ZRIN) samples show the most prominent zircon age groups between c. 645 and c. $270 \mathrm{Ma}(78 \%$ and $84 \%$, respectively). These samples also contain a few Cryogenian-Ediacaran (c. 680-780 Ma), early Neoproterozoic to Mesoproterozoic (c. 1.3-0.9 Ga), Palaeoproterozoic (c. 2.2-1.6 Ga) and Archean (c. 2.5-3.4 Ga) grains, but their abundances are relatively low.

Sample ZRIN provided 79 concordant results, out of 94 analyses, ranging c. 2778-169 Ma. The zircon ages are mainly late Silurian to Carboniferous, spreading between c. $419 \mathrm{Ma}$ and c. $291 \mathrm{Ma}(55 \%$; with a peak at c. $330 \mathrm{Ma})$, which can be grouped into two clusters: c. 372-291 Ma (46 \%) and c. 419-384 Ma (9 \%) (Fig. 3). This sample provided the youngest age measured in this research $(168.8 \pm 2.1 \mathrm{Ma})$ and a Permian zircon $(271.7 \pm 8.5 \mathrm{Ma})$. ZRIN also yields distinguishable late Ediacaran to early Cambrian (c. 625-536 Ma; $16 \%$ ) and late Mesoproterozoic to early Neoproterozoic populations (c. 1247-872 Ma; $13 \%$ ) along with a few Palaeoproterozoic and Archean ages.

Of 177 analyses in ZSLN, 155 yielded concordant results, ranging c. 3388-279 Ma. The most frequent zircon age populations are early Carboniferous to early Permian (Fig. 3), varying in age between c. 359 and c. $293 \mathrm{Ma}$ ( $43 \%$; peak at c. $330 \mathrm{Ma}$ ) and early Ediacaran to late Ordovician with ages between c. $610 \mathrm{Ma}$ and c. $464 \mathrm{Ma}(29 \%$; peak at c. $550 \mathrm{Ma}$ ). Three discordant ages cluster near c. $280 \mathrm{Ma}$. A few zircons yielded Silurian-Devonian (c. 421$375 \mathrm{Ma} ; 4 \%$ ) and Cryogenian-Ediacaran (c. 735-620 Ma; $7 \%$ ) ages. 
Fig. 3 Histogram, Kernel density estimations and pie diagrams for the Berriasian to Turonian sediments deposited in nearshore to distal deltaic environments. Total number of age results and concordant ages are indicated by " $n$ ". Concordant data represented by filled diagrams, while the stroked diagrams show entire data set within each interval. Inner circle in pie diagram refers to the concordant data and the outer circle to the entire data set
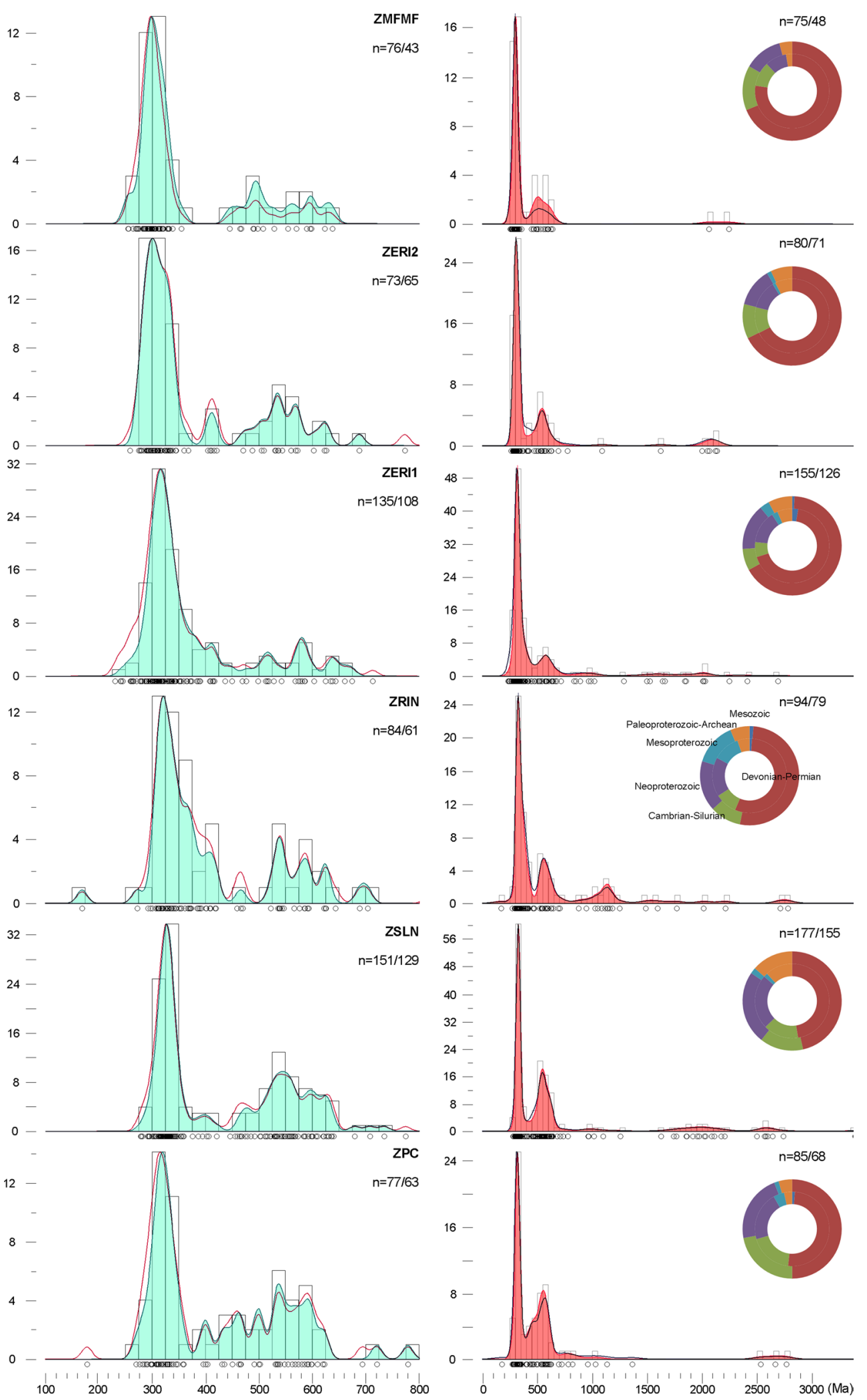

\section{Upper Barremian-lower Aptian (ZERI1)}

Out of 154 analyses from sample ZERI1, 126 yielded concordant ages. Sample ZERI1 contains zircon between c.
2687 and c. $230 \mathrm{Ma}$, although most zircon younger than 289 Ma gave discordant results (Fig. 3). The majority of the concordant zircon is middle Devonian to upper Permian, between c. $390 \mathrm{Ma}$ and c. $259 \mathrm{Ma}(65 \%)$, with a dominant 
Fig. 4 Histogram, Kernel density estimations and pie diagrams for the upper Aptian-lower Albian samples. Supplementary explanation in this legend
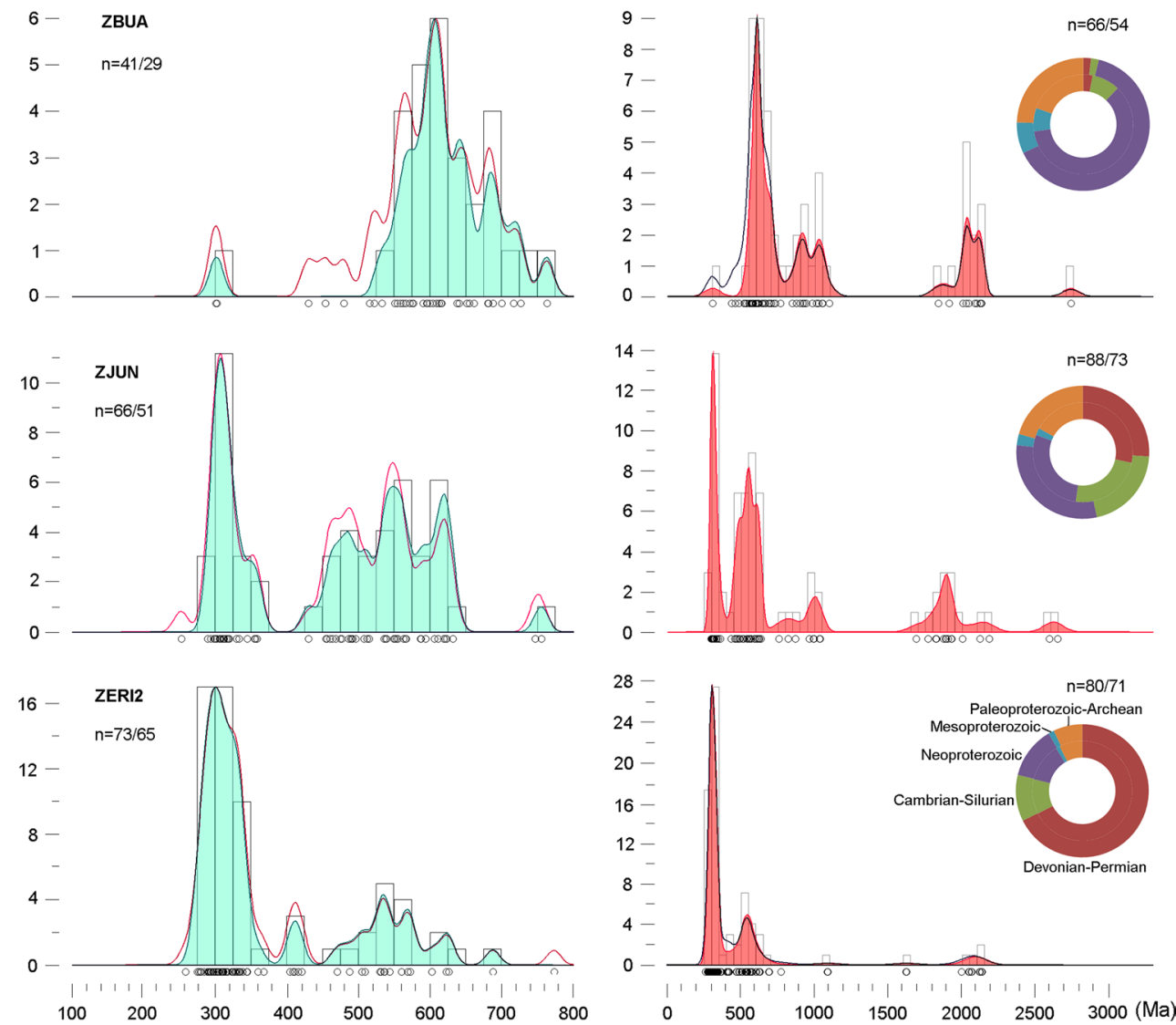

peak at c. 320 Ma. The second most prominent group of ages is late Cryogenian to early Ordovician, spanning c. 674-476 Мa (16\%). A minor cluster of early Devonian zircon (c. 417-408 Ma; $4 \%$ ) is also present. A few grains yielded ages older than $830 \mathrm{Ma}$, with clusters between $\mathrm{c}$. $1017-886 \mathrm{Ma}(2 \%)$ and c. $2.0-1.6 \mathrm{Ga}(6 \%)$.

\section{Upper Aptian-Albian (ZERI2, ZJUN and ZBUA)}

The three analysed upper Aptian to Albian samples (ZERI2, ZJUN and ZBUA) show very different age signatures (Fig. 4). A total of 80 analyses from sample ZERI2 provided 71 concordant ages. Detrital zircon has an age range of c. 2133-258 Ma. Carboniferous to early Permian results (c. 344-275 Ma), with a maximum frequency peak at c. $320 \mathrm{Ma}$, are clearly dominant (62\% of concordant zircon). Ediacaran to early Ordovician, with an age range of $c$. 626-470 Ma, constitutes the second most prominent cluster (23\%). A few grains yielded ages ranging c. 416-409 Ma (4\%) and c. 2.1-2.0 Ga (6\%). No Archean zircon was found.

Out of 88 analyses from sample ZJUN, 73 gave concordant ages. Zircon grains range in age between $\mathrm{c}$. $2646 \mathrm{Ma}$ and c. $252 \mathrm{Ma}$, although the youngest concordant age is $294 \mathrm{Ma}$. Most concordant zircon ages belong to two groups: Ediacaran to Ordovician, spanning between c. 632 and $454 \mathrm{Ma}(41 \%)$, with a frequency peak at c. $530 \mathrm{Ma}$; and early Carboniferous to early Permian, spanning between c. 358 and $294 \mathrm{Ma}(26 \%)$, with a frequency peak at c. $320 \mathrm{Ma}$. Late Mesoproterozoic to early Neoproterozoic (c. 1033-755 Ma; $11 \%$ ), Palaeoproterozoic (c. 2.2-1.7 Ga; $18 \%$ ) and Archean (c. $2.6 \mathrm{Ga} ; 2 \%$ zircon constitute secondary age groups.

A total of 66 analyses from sample ZBUA yielded 54 concordant ages. The detrital ages range between $c$. 2733 Ma and c. $301 \mathrm{Ma}$, although most Palaeozoic grains (75\%) are discordant. The sample is clearly dominated by early Palaeozoic and Neoproterozoic ages, spanning c. $763-532 \mathrm{Ma}(52 \%)$, with a peak at c. $620 \mathrm{Ma}$, which includes mid-late Cryogenian (c. 763-637 Ma; $22 \%$ ) and Ediacaran-Cambrian (c. 616-551 Ma; $28 \%$ ) clusters. Early Neoproterozoic to late Mesoproterozoic (c. 1094-844 Ma; $22 \%$ ) and Palaeoproterozoic (c. 2.1-1.8 Ga; $22 \%$ ) zircon constitute secondary groups. One Archean age (c. $2.7 \mathrm{Ga}$ ) was found.

\section{Turonian (ZMFMF)}

Of 75 analyses from sample ZJUN, only 48 provided concordant ages. The detrital zircons from this sample range 
between c. $2240 \mathrm{Ma}$ and c. $254 \mathrm{Ma}$, but the majority of the Pennsylvanian to Permian results is discordant (51\%). Most concordant ages are Carboniferous-Permian, spanning c. 354-254 Ma (69\%), with a clearly dominant peak at c. $300 \mathrm{Ma}$ (Fig. 3). A secondary group has a general spread of ages between c. $637 \mathrm{Ma}$ and c. $445 \mathrm{Ma}(27 \%)$, with distinct frequency peaks at approximately c. $595 \mathrm{Ma}$ and c. $485 \mathrm{Ma}$. Zircon older than the Ediacaran is uncommon (2 Palaeoproterozoic grains of c. 2.1 and $2.2 \mathrm{Ga}$ ).

\section{Discussion}

\section{Phases of zircon generation}

\section{Archean to Cryogenian (>670 Ma)}

Zircon ages older than c. $670 \mathrm{Ma}$ are inherited from Precambrian continent assembly and break-up events such as the Pan-African (<800 Ma), Grenvillian (c. 1.2-0.9 Ga) and Eburnean (c. 2.1-1.7 Ga) (Nance et al. 2014). Except for ZBUA, where zircon older than 670 Ma constitutes the majority of the age spectra, and to lesser extent ZJUN and ZRIN, the abundances of Archean to Cryogenian zircon are residual. Eburnean zircon ages are widespread in the Iberian Massif metamorphic rocks, while Grenvillian ages are uncommon in central west locations but frequent in the lower Palaeozoic and Neoproterozoic successions from north-west Iberia (Fernández-Suárez et al. 2002, 2013; Martínez Catalán et al. 2004; Shaw et al. 2014). The majority of these ages have in common high $\mathrm{Th} / \mathrm{U}$ ratios, indicative of probable igneous generation (Fig. 5).

\section{Late Neoproterozoic to early Palaeozoic (c. 660-460 Ma)}

The late Neoproterozoic to early Palaeozoic ages form three distinct groups (Fig. 6). The oldest zircons, 660-540 Ma, may be linked to Cadomian-Avalonian orogenic belts or younger Pan-African events. Age peaks of approximately $620 \mathrm{Ma}, 600-580 \mathrm{Ma}$ and $565 \mathrm{Ma}$ within this interval broadly coincide with the age clusters referred to by Pereira et al. (2011) for Cadomian magmatism in south-west Iberia. The occurrence of low $\mathrm{Th} / \mathrm{U}$ zircon with c. $560 \mathrm{Ma}$ is also a common feature of the Cadomian-related population from south-west Iberia and the Cretaceous succession (Fig. 5). The 540-530 Ma age group, with largest age peak at c. $536 \mathrm{Ma}$, corresponds to an early Cambrian thermal event responsible for voluminous plutonism in west Europe (Linneman et al. 2008). Crystalline rocks of this age are well represented in the Palaeozoic of Iberia (Talavera et al. 2012; Pastor-Galán et al. 2013). Middle Cambrian to middle Ordovician ages (c. 530-460 Ma) are probably linked to arc-related magmatism (Díez Fernández et al. 2012) and subsequent events associated with the opening of the Rheic Ocean that are found in several regions of the Variscan Iberian Massif (Valverde-Vaquero and Dunning 2000; Díez Montes et al. 2010; Chichorro et al. 2008; Solá et al. 2008; Liesa et al. 2011). The proportions of these age groups are highly variable and do not correlate with each other, suggesting that they were derived from distinct regions and source units. ZBUA is distinguished from the remaining samples by the high amount of 660-540 Ma and absence of 530-460 Ma zircon.

\section{Late Silurian to middle Devonian (c. 420-385 Ma)}

Silurian to middle Devonian zircon constitutes a relatively low-frequency group but distinguishable from the older and younger populations recognized in the Berriasian to Albian samples from the Ericeira region (ZPC, ZSLN, ZRIN, ZERI1 and ZERI2). Examination of a Kernel density diagram for this group of zircon ages (Fig. 6) suggests two events of zircon generation, with highest frequencies at c. $410 \mathrm{Ma}$ and c. $387 \mathrm{Ma}$. The later approximately coincides with the Acadian orogeny from north-east America, while the former is slightly older than the Neo-Acadian ( 380-370 Ma) orogeny (van Staal et al. 2009; Murphy et al. 2011). This age group could be derived from the allochthonous ophiolitic complexes of north-west Iberia that integrate magmatic and metamorphic rocks with relevant amounts of Silurian-Devonian zircon (Crowley et al. 2000; Martínez Catalán et al. 2008; Arenas et al. 2013). Syn-Variscan basins from south-west Iberia are also characterized by the presence of a single population of mainly middle Devonian age (peak at c. $390 \mathrm{Ma}$ ) that is supposedly derived from a magmatic arc associated with the closure of Rheic Ocean (Pereira et al. 2012a, 2013).

\section{Late Devonian to early Permian (c. 375-280 Ma)}

Zircon ages ranging between 375 and 280 Ma should primarily be sourced from crystalline rocks of the west European Variscan belt. Given that there is a continuum of zircon ages throughout the late Devonian to Permian interval, it is not easy to establish individual events of zircon generation. The occurrence of zircon displaying wide variable $\mathrm{Th} / \mathrm{U}$ ratios (Fig. 5) and both oscillatory and convolute/ irregular zoning suggests association with both magmatic and metamorphic processes.

Density plots are dominated by ages between 280 and $354 \mathrm{Ma}$ with a maximum peak of c. $319 \mathrm{Ma}$, followed by peaks at c. $330 \mathrm{Ma}$ and c. $299 \mathrm{Ma}$ (Fig. 6). The two older age maximums are compatible with the Variscan syn- to post-collisional phases of plutonism in Iberia (e.g. Dias et al. 1998; Fernández-Suárez et al. 2000; Jesus et al. 2007). The younger peaks may be related to subsequent 
Fig. 5 Plot of zircon age and respective $\mathrm{Th} / \mathrm{U}$ ratios
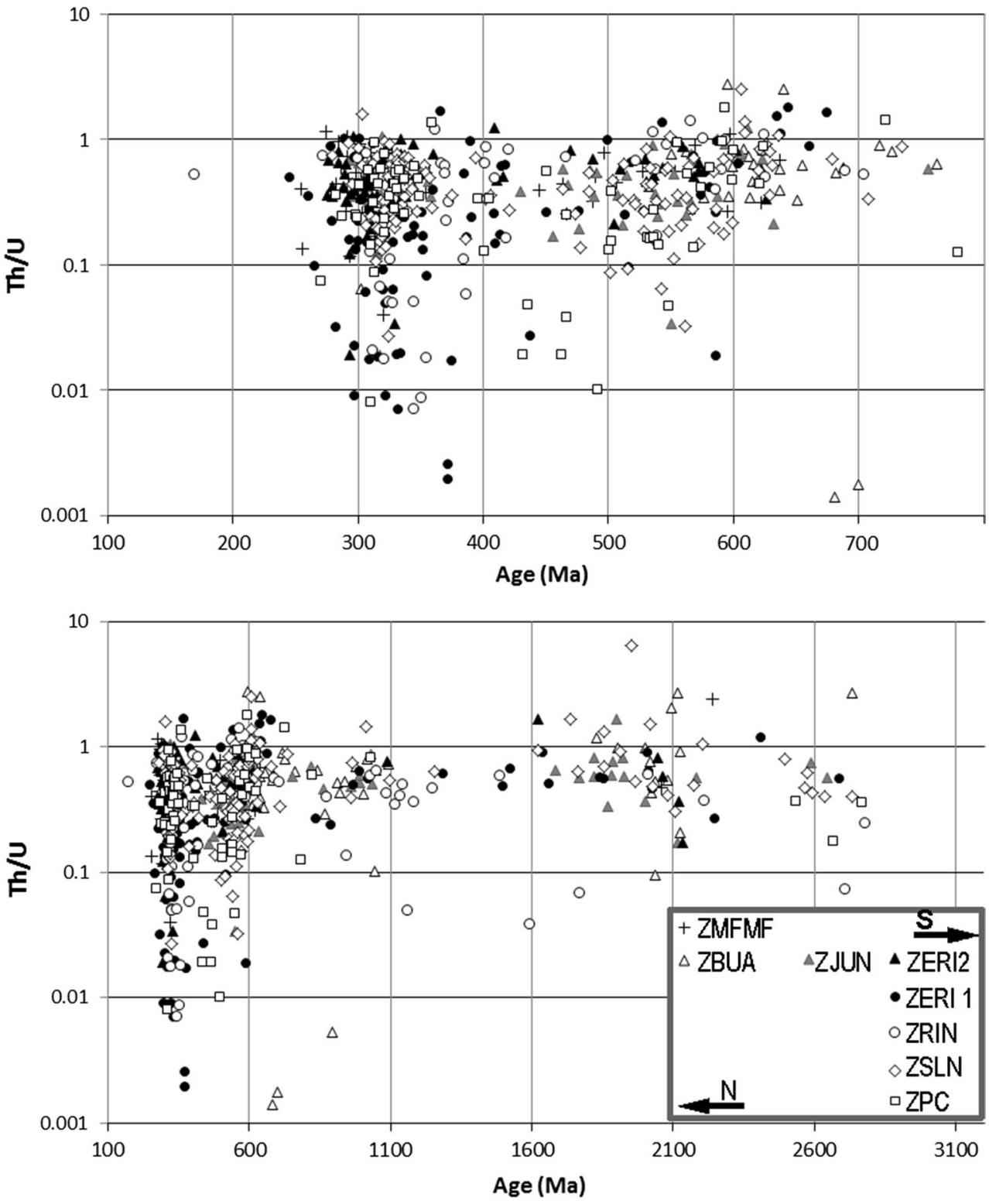

delamination (Gutiérrez-Alonso et al. 2004, 2011; PastorGalán et al. 2013) or the subduction of Palaeotethys and development of a Palaeotethyan arc in Iberia (Pereira et al. 2014). Several sources may be postulated for the ages older than $355 \mathrm{Ma}$. These include some geological units coeval with felsic volcanics from south-west Iberia (Rosa et al. 2009) or crystalline rocks related to the accretion of Meguma terrane with Laurentia continent (Clarke et al. 1997; Moran et al. 2007; Murphy et al. 2011).

\section{Permian-Jurassic $(<270 \mathrm{Ma})$}

Only two zircon grains yielded concordant Mesozoic ages (169 and $244 \mathrm{Ma}$ ). The relatively high $\mathrm{Th} / \mathrm{U}$ ratios (Fig. 5) suggest that they are both magmatic in origin. The youngest zircon can be linked to middle to late Jurassic magmatism associated with the break-up of Pangea, e.g. reported SHRIMP ages from the Betic Cordillera (Puga et al. 2011). Late Permian to Triassic thermal events, probably associated with the closure of Palaeotethys, are recognized in eastern Europe (e.g. Koralay et al. 2001; Poller et al. 2002), but such ages are more likely to be derived from igneous rocks generated during the earlier stages of extension, such as those associated with the basic magmatism observed in west Iberia (Gardien and Paquette 2004; Orejana et al. 2008). Gardien and Paquette (2004) found zircon with rim ages of c. 240-270 Ma in amphibolitic rocks from the Iberia Abyssal Plain and attributed them to mantle melts with reheating of the lower crust. Zircons with complex zoning and low $\mathrm{Th} / \mathrm{U}$ (Fig. 5) are probably sourced by these units or comparable rocks. 


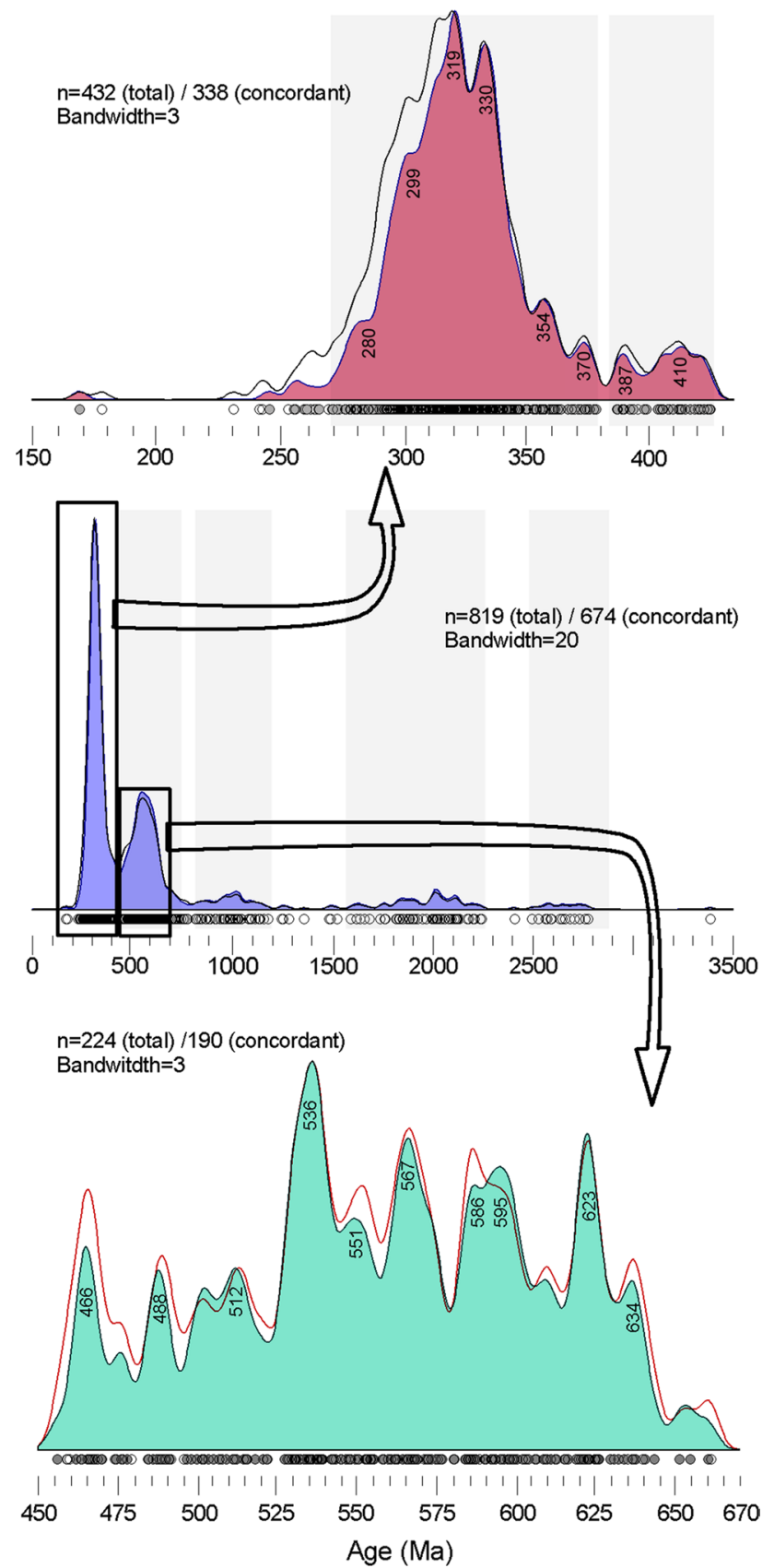

Fig. 6 Compilation of all zircon age data and resulting main phases of zircon generation. Concordant data represented by filled diagrams. Stroked diagrams show entire data set within each interval

\section{Local versus regional provenance}

An obvious distinguishing feature arises from the analysis of the set of Cretaceous samples: sediments deposited in marine or distal positions of the fluvio-deltaic systems (samples ZPC, ZSLN, ZRIN, ZERI1, ZERI2 and ZMFMF) contain higher proportions of middle-late Palaeozoic zircon contrasting with those from proximal fluvial environment (samples ZJUN and ZBUA), which yield higher amounts of early Palaeozoic and Proterozoic ages. This difference is clearly shown on the MDS map whereby ZJUN and ZBUA occupy very difference space, away from the main cluster of samples (Fig. 7). ZJUN yields a significant amount of Cambro-Ordovician zircon, while ZBUA has a large number of Cadomian (or late Pan-African), Grenvillian and Eburnean ages (Fig. 8). ZBUA is also the only sample with significant abundance of early Pan-African ages. To account for these differences, the catchment areas of ZJUN and ZBUA require increased contributions from the Central Iberian Zone and Ossa Morena Zone, respectively. The Slate and Greywacke Complex, which was probably the most prominent non-crystalline unit within the Central Iberian Zone, is distinguished from the Ediacaran to lower Palaeozoic metasediments of the Ossa Morena Zone by the presence of significant amounts of zircon ranging c. 800-650 Ma (Pereira et al. 2012b).

Sample ZERI2 can be considered to be broadly equivalent in age with ZBUA and ZJUN, but its detrital zircon signature more closely resembles the other nearshore samples (ZPC, ZSLN, ZRIN, ZERI1 and ZMFMF). Overall, the fluvial sediments deposited in proximal locations (ZBUA and ZJUN) contain significant proportions of early Palaeozoic and Precambrian zircon contrasting with the samples from more distal locations, which have a detrital age signature dominated by late Palaeozoic zircons, consistent with most of the Variscan crystalline rocks being exposed by that time. The presence of a dominant Variscan population is a characteristic feature of the units with larger source areas that integrated sediment delivered by both fluvial systems and coastal processes.

\section{Regional evolutionary trends of sediment delivery}

It is possible to recognize time-dependent trends in the abundances of each detrital age populations (Fig. 9). Considering only the concordant results, late Permian to Devonian zircon constitutes approximately $45 \%$ of the detrital record in older sediments; the abundances of this population rise suddenly after the Barremian unconformity (i.e. between ZRIN and ZERI1) to $60 \%$ and keep increasing in a slow but sustained rate upwards (slightly higher figures are found if discordant ages are also included). The progressive increase in the amount of late Devonian to Permian zircon throughout the succession may be attributed to increased depths of erosion and the progressive exhumation of younger crystalline rocks. The marked change in the abundance of late Palaeozoic zircon after the Barremian unconformity, with consistently lower values below and higher values above, would be consistent with an episode of major structural reorganization within Iberia and Newfoundland conjugate margins. 
Fig. 7 MDS map grouping samples with similar age spectra, and pulling apart samples with different spectra, using the KS effect size as a dissimilarity measure (Vermeesch 2013). The plot shows a cluster of samples with similar age spectra on the left-hand side

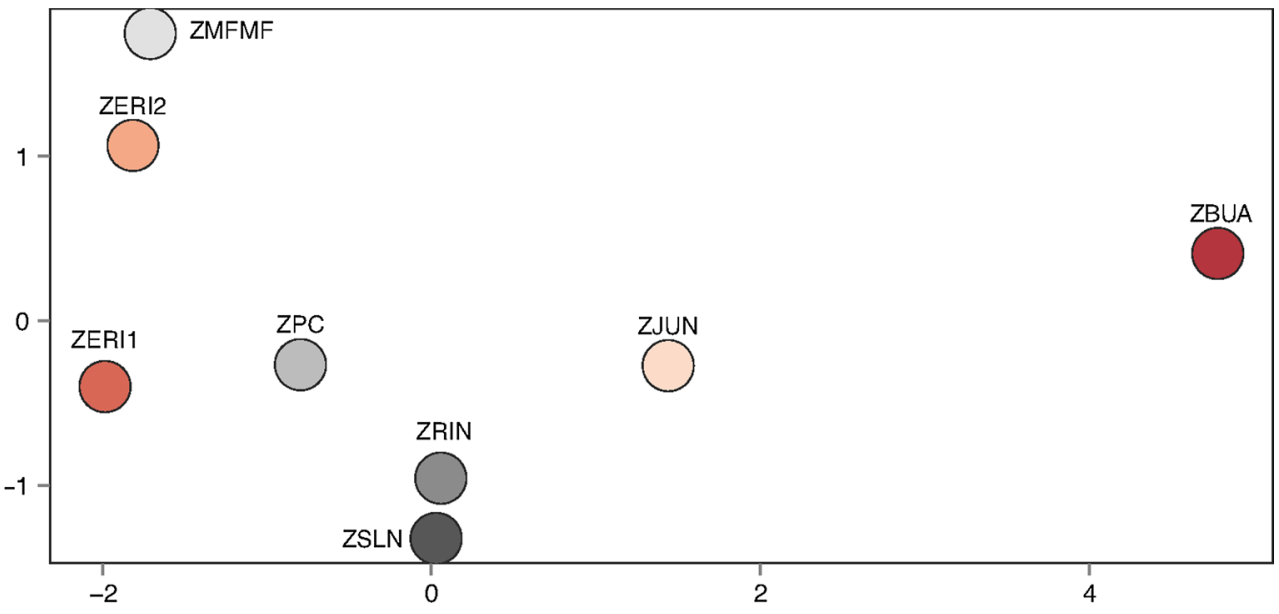

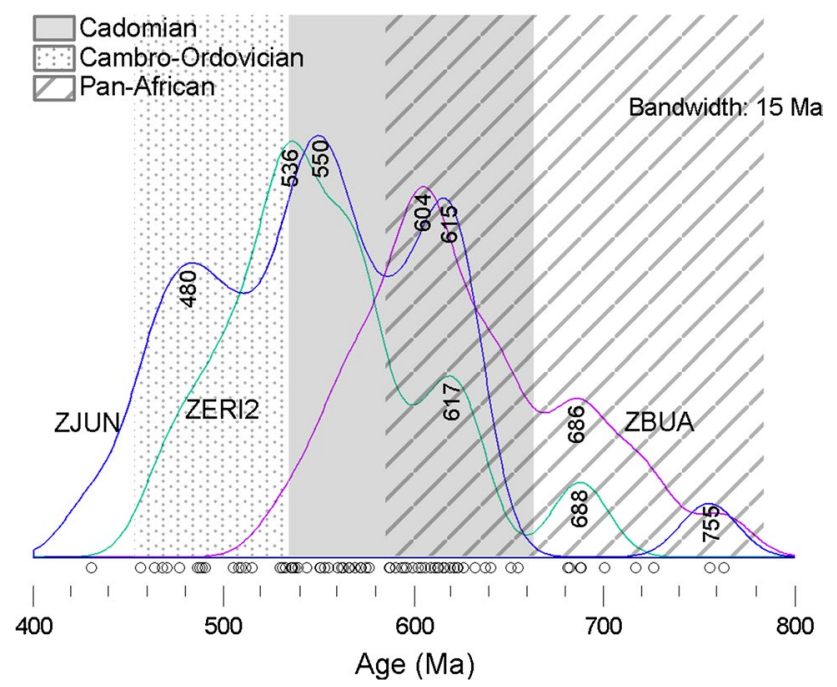

Fig. 8 Kernel density estimations and reported zircon-forming events within 800- to 400-Ma interval for the upper Aptian to lower Albian sample beds

The Barremian unconformity also marks a key position in the abundances of other age modes. Zircon ages of $\mathrm{c}$. 420-385 Ma and 1.2-0.9 Ga, which are relatively uncommon in central west Iberia basement rocks that currently outcrop in west central Iberia, attain maximum abundances in ZRIN (i.e. below the Barremian unconformity). Conversely, the lowest abundance of Cambro-Ordovician ages among the nearshore samples is observed in ZRIN (Fig. 9). Moreover, ZRIN displays an age cluster of approximately $370 \mathrm{Ma}$, which is slightly older ( 10 Ma) than the majority of the Variscan events of zircon generation recognized in Iberia (e.g. Dias et al. 1998; Fernández-Suárez et al. 2000; Jesus et al. 2007). However, this age is compatible with igneous activity on the west Atlantic conjugate margin (Dunning et al. 2002). Based on these findings, one can speculate that such ages may be sourced from Laurussia or recycled from older sedimentary rocks that had a pre-Atlantic opening source from the west. Carboniferous-Permian continental clastic rocks that presently outcrop on the north Atlantic margins probably occupied wider areas during Cretaceous times than today (Piper et al. 2012), including the north-west Iberian margin (Capdevila and Mougenot 1988). Such rocks may integrate sediment derived from Laurussia, Gondwana and peri-Gondwana terranes constituting plausible sources for the c. 1.2-0.9 Ga and c. 420 $385 \mathrm{Ma}$ age populations along with the c. $370 \mathrm{Ma}$ ages.

Variable contributions of distinct phases of zircon generation within the late Devonian to Permian interval (referred before) and a clear shift to higher frequency of younger ages in younger sediment beds are revealed by the Kernel density curves of Fig. 10. The frequency of latest Carboniferous to Permian zircon, with maxima of c. 308-292 Ma, could be associated with the post-Variscan delamination (Gutiérrez-Alonso et al. 2004, 2011; Pastor-Galán et al. 2013) or the subduction of Palaeotethys (Pereira et al. 2014). These ages are particularly abundant in the late Aptian-early Albian (ZERI2 and ZJUN; ZBUA yielded only one late Palaeozoic age of c. $301 \mathrm{Ma}$ ) and Turonian (ZMFMF) samples. This pattern contrasts with the older sediments where late Devonian to middle Pennsylvanian ages, with maxima of c. 336-313 Ma, coinciding with the main phases of collisional magmatism (Dias et al. 1998; Fernández-Suárez et al. 2000; Jesus et al. 2007; PastorGalán et al. 2013), clearly dominate.

\section{Implications for East Atlantic palaeogeography and palaeodrainage}

One of the most striking features of the studied Cretaceous detrital zircon record is the presence of a stepwise shift in the abundance of late Devonian to Permian zircon (c. 375275 Ma; Fig. 9) after the Barremian unconformity, which is balanced by a decrease of $1.2-0.9 \mathrm{Ga}$ and $420-385 \mathrm{Ma}$ 
Fig. 9 Estimated proportions of the main populations recognized in the studied succession. Age populations are linked to respective most likely zirconforming events. Samples united by line are from nearshore to deltaic environments (ZPC, ZSLN, ZRIN, ZERI1, ZERI2 and ZMFMF). The other two samples are from fluvial environments (ZJUN and ZBUA). Summed proportions constitute $82-90 \%$ of the entire detrital age record in each sample

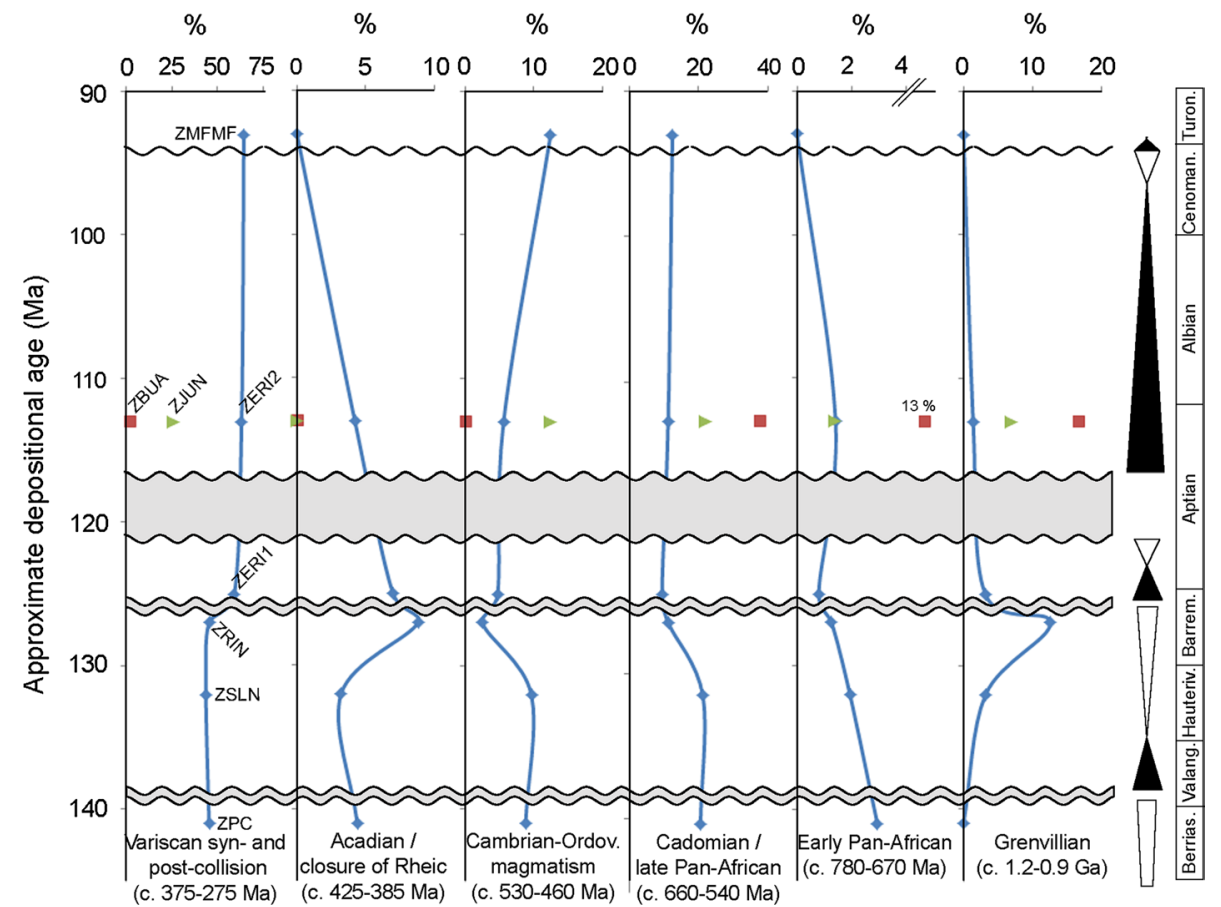

populations; two age groups that are poorly represented in west central Iberia, but common in several units from NW Iberia and in the west Atlantic conjugate margin (Crowley et al. 2000; Fernández-Suárez et al. 2002, 2013; Martínez Catalán et al. 2004, 2008; Arenas et al. 2013; Shaw et al. 2014). We propose that these age groups were derived via a south-directed routing system that drained the Galicia Bank-NW Iberia area and was active throughout the early Cretaceous, until just before the Barremian unconformity. At this time, the Grand Banks basins were fed from the south-east (Tankard and Welsink 1987; Lowe et al. 2011) and were separated from Iberian margin by the topographic barriers of the Avalon High, Flemish Cap and Galicia Bank (Fig. 11). After the separation of the Galicia Bank from the Flemish cap, a deep connection was established between the central and northern Atlantic seas and the contribution of sediment delivered from NW Iberia and adjoining western areas decreased abruptly. This event is coeval with uplift and block tilting of the onshore continental areas (Whitmarsh and Wallace 2001; Alves et al. 2009), promoting exhumation of late Palaeozoic crystalline rocks from continental Iberia. The combined effects of these two changes (suppression of the southward supply and increase in the exhumation of crystalline Variscan rocks) explain the shift in detrital zircon record between pre- and post-Barremian unconformity sedimentary rocks.

The upper Aptian unconformity, which records a pronounced change in the sedimentary architecture and which can be traced across the two conjugate margins (Tucholke and Sibuet 2007; Tucholke et al. 2007; Dinis et al. 2008), as well as in other west European basins (Jacquin et al. 1998), is not associated with a shift in zircon provenance, as seen for the Barremian unconformity. The modest change in zircon peak ages from 330-310 Ma to 310-290 Ma, across the upper Aptian unconformity (Fig. 10), indicates that the post-Variscan (i.e. late Carboniferous to Permian) crystalline rocks were widely exhumed at this time and were the main sources of sediment. Intense erosion after the late Aptian was likely associated with the thermal and isostatic readjustment of the north-west area of the Iberian microplate (Hiscott et al. 1990; Dinis and Trincão 1995; Dinis et al. 2002). At this time, most fluvial systems in northern locations of the west Iberian margin were probably relatively small and the streams incision was limited, producing an age fingerprint in ZBUA that, except for the presence of residual proportions of Palaeozoic zircon, resembles the age signatures reported for the Ediacaran to Lower Cambrian metapelites from western locations of the Central Iberian Zone (Talavera et al. 2012; Pereira et al. 2012b). Conversely, the earlier rifting and seafloor spreading processes in southern Iberia, and consequently more prolonged development of the drainage systems, account for the higher amount of Variscan ages in ZJUN.

Based on the distribution of the post-Variscan magmatic rocks in the tectonostratigraphic zones of north-west Iberia (Gutiérrez-Alonso et al. 2011), showing younger plutons in the inner orocline Cantabrian and west Asturian-Leonese zones (with crystallization ages in the interval c. 300$285 \mathrm{Ma}$ ) with respect to the relatively older Central Iberian Zone plutons (preponderance of c. 310-305 Ma), the 
Fig. 10 Kernel density estimations with peaks of maximum frequency for each sample within the 375- to $270-\mathrm{Ma}$ interval. Zircon-forming events discussed in the text are identified

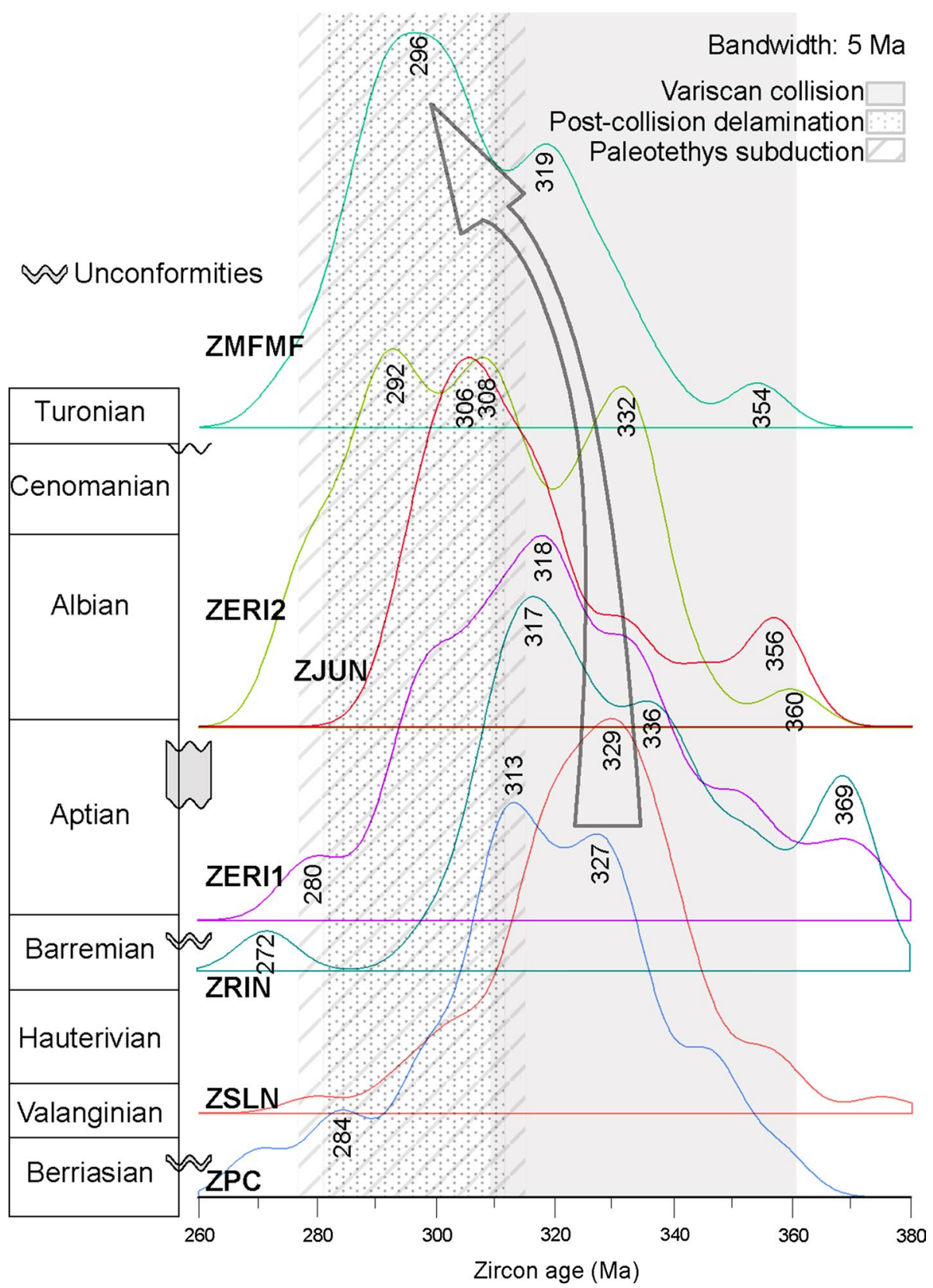

younger peaks in younger sedimentary rocks suggest that the delivery systems reached the former zones (Fig. 11). Besides fluvial drainage, the sediment transport should also involve marine currents that carried sediments from coastal areas of Bay of Biscay. A surface circulation compatible with this transport in eastern Atlantic is assumed for the Aptian-Albian (Trabucho Alexandre et al. 2011).

\section{Conclusions}

The detrital zircon record of Cretaceous sedimentary rocks of the Lusitanian basin, sourced from large drainage areas (samples ZPC, ZSLN, ZRIN, ZERI1, ZERI2 and ZMFMF), contains a dominant population of late Palaeozoic ages (c. 375-275 Ma), contrasting with the more proximal sediments (samples ZBUA and ZJUN), which yield higher amounts of early Palaeozoic and Proterozoic zircon. Examination of the detrital zircon age spectra from samples with wider supplying areas reveals important changes in the sediment routing system. A comparison of the samples collected before (ZPC, ZSLN and ZRIN) and after (ZERI1, ZERI2 and ZMFMF) the Barremian unconformity indicates a marked increase in the abundance of late Palaeozoic ages in the succession that covers this surface. Sample ZRIN, immediately below the Barremian unconformity, 

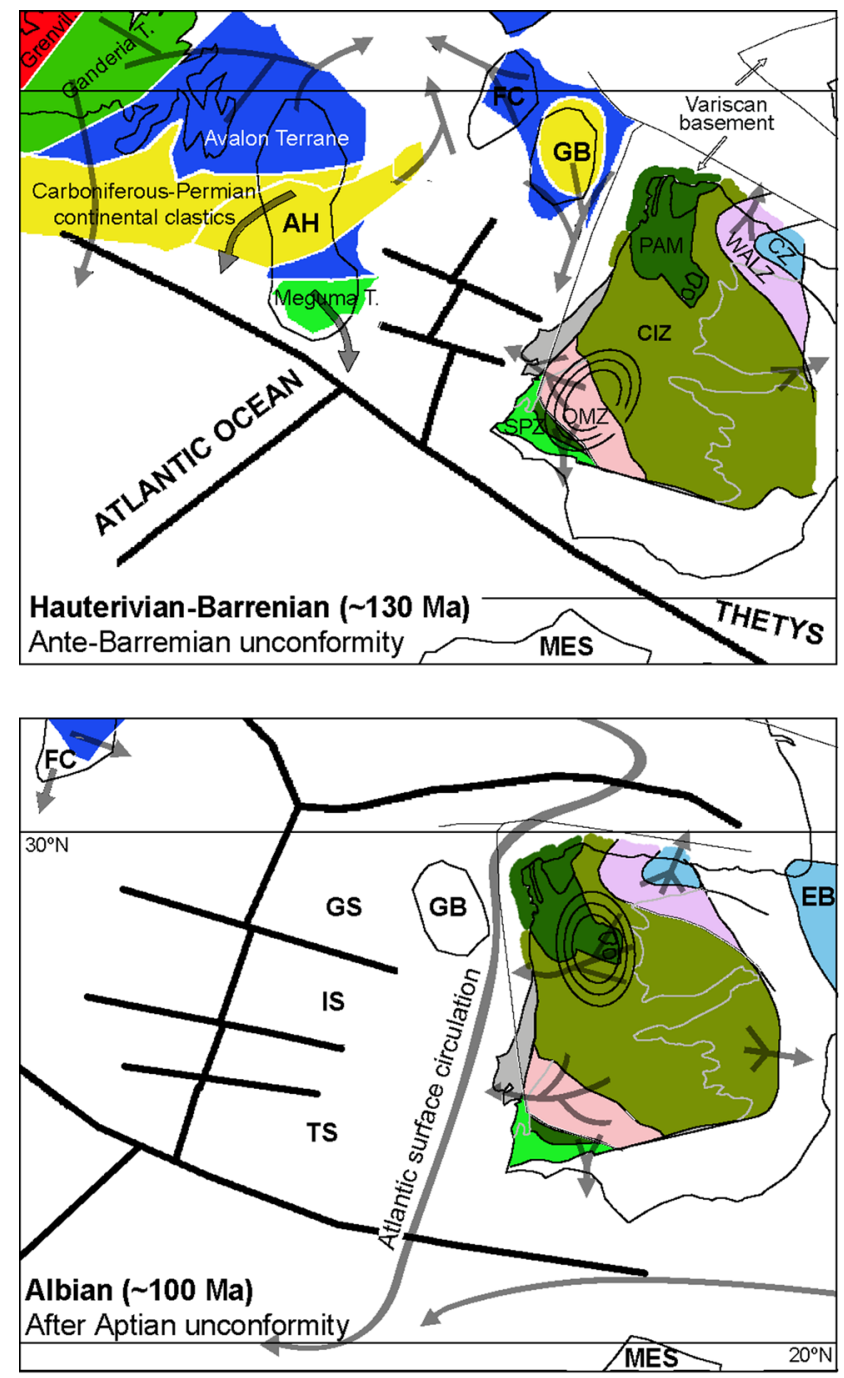

Fig. 11 Model for the distribution of zircon source units and delivery system in the region around the Iberian microplate. Concentric ellipses represent the areas expected to be under higher uplifting in the Iberian Atlantic margin. Position of the continents based on Dercourt et al. (2000), Sahabi et al. (2004) and Sibuet et al. (2012). Morocco Meseta, Flemish Cap, Galicia Bank and Avalon High are reference locations from Sibuet et al. (2012). Presently exposed Lusitanian basin (grey patch) and the current extension of the Mesocenozoic Iberian cover (grey line) are also indicated. Main zircon age populations (Mesoproterozoic to Palaeozoic) found in the Iberian

also contains the highest amounts of c. 1.2-0.9 Ga and c. 420-385 Ma populations and a secondary peak of c. $370 \mathrm{Ma}$. The late Aptian unconformity which is classically referred to has the break-up unconformity, representing a major rupture in the stratigraphic record in both Iberia and its Newfoundland conjugate margin and the largest hiatus in the sedimentary record, does not mark a clear modification in the proportions of the most common age populations, but has correspondence with a shift of the maximum frequency peak to younger ages (c. 310-305 Ma in ZPC,

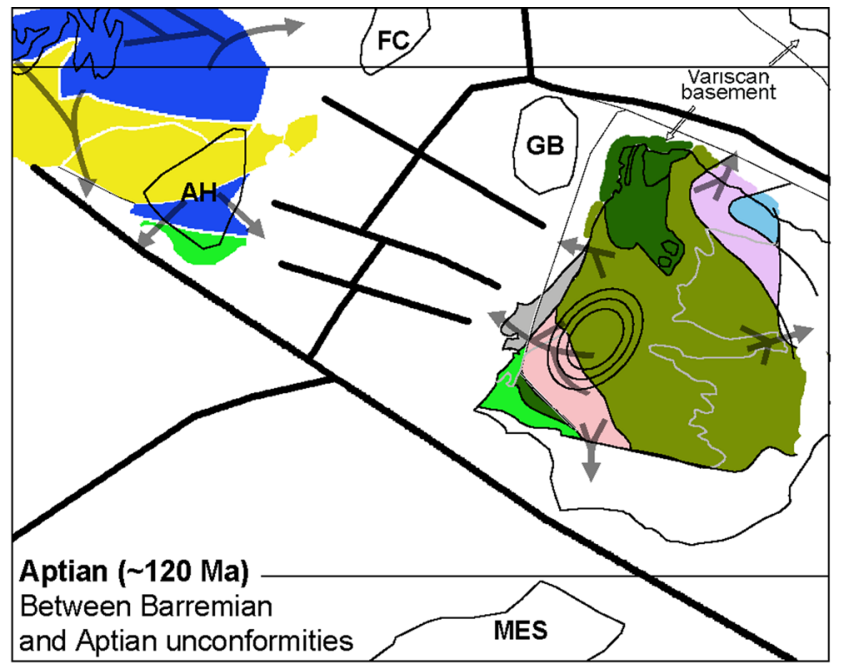

Cantabrian Zone
(300-285 Ma; 520-460 Ma; 800-560 Ma; 1.1-0.9 Ga)

West Asturian-Leonese Zone

WALZ (300-285 Ma; 750-550 Ma; 1.1-0.9 Ga)

Central Iberian Zone

(310-295 Ma; 490-450 Ma; 550-850 Ma; 1.1-0.9 Ga, less

common in central west locations)

Ossa Morena Zone

OMZ (locally 390-360 Ma; 700-480 Ma)

Para-authochnous/allochnous massifs with ophiolitic units

(mainly associated with the closure of Rheic Ocean)

(750-500 Ma; 1.1-0.9 Ga)

South Portuguese Zone (Meguma basement?)

(locally 380-350 Ma; 800-460 Ma)

Meguma Terrane (Neoacadian orog. c. 380-370 Ma)

Avalon Terrane (Acadian orogeny c. 420-400 Ma) Peri-Gondwana terranes

Ganderia Terrane (Salinic orogeny c. 440-425 Ma)

Grenvillian basement (1.2-0.9 Ga igneous and metamorphic rocks)
GB: Galicia Bank

FC: Flemish Cap

AH: Avalon High
GS: Galicia Sector
IS: Iberian Sector

TS:: Tagus Sector
EB: Ebro Block

MES: Morocco Meseta tectonostratigraphic zones from Fernández-Suárez et al. (2000, 2002, 2013), Gutiérrez-Alonso et al. (2004, 2011), Martínez Catalán et al. (2004, 2008), Valle Aguado et al. (2005), Jesus et al. (2007), Linnemann et al. (2008), Rosa et al. (2009), Pereira et al. (2010, 2011, 2012a, b), Díez Fernández et al. (2010), Talavera et al. (2012), PastorGalán et al. (2013) and Shaw et al. (2014). Accretion ages of periGondwana and terranes and corresponding orogenies according to van Staal et al. (2009) and Murphy et al. (2011). Sediment paths in Newfoundland conjugate margin from Lowe et al. (2011) and Piper et al. (2012)

ZSLN, ZRIN and ZERI1; c. 300-285 Ma in ZERI2, ZJUN and ZMFMF).

Except for the c. $370 \mathrm{Ma}, 420-385 \mathrm{Ma}$ and 1.2-0.9 Ga zircon, which are characteristic of NW Iberia, the main age populations are common in the Variscan Iberian Massif to the east of the Lusitanian basin. The increase in the abundance of late Palaeozoic zircon reflects the advance of the denudation of the Variscan crystalline rocks after intense uplift in central and southern locations of the Iberian Massif. The Barremian unconformity is also represented by a 
significant decrease in the abundances of the age clusters probably derived from NW Iberia. The changes after the Barremian unconformity should be linked with the separation of the Galicia Bank from Flemish Cap and the development of a dip link between Central and North Atlantic. This morphological transformation along the Atlantic margin was responsible for a significant decrease in the supply of sediments with Laurussia affinity or association with the closure of the former Rheic Ocean (c. 370 Ma, 420-385 Ma and 1.2-0.9 Ga) and the establishment of an almost exclusively central Iberian subplate provenance. It is assumed that the shift to younger maximum frequency peaks after the Aptian unconformity results from the uplift and reorganization of the sediment delivery systems in northern locations of the Iberian subplate. Part of the younger zircon (<c. $300 \mathrm{Ma}$ ) was probably transported southward from the Bay of Biscay under the influence of an already well-established southward Atlantic circulation.

Acknowledgments Project SFRH/BSAB/1233/2011 from the Portuguese Foundation for Science and Technology (FCT) and an Iberoamerican Santander grant provided funding for the laboratory work at University of São Paulo. We are grateful to the reviewers Wilfried Winkler and Manuel F. Pereira and the topic editor Axel Gerdes for their constructive comments.

\section{References}

Afilhado A, Matias L, Shiobara H, Hirn A, Mendes-Victor L, Shimamura $H$ (2008) From unthinned continent to ocean: the deep structure of the West Iberia passive continental margin at $38 \mathrm{~N}$. Tectonophysics 458:9-50. doi:10.1016/j.tecto.2008.03.002

Alves TM, Gawthorpe RL, Hunt DW, Monteiro JH (2003) Post-Jurassic tectono-sedimentary evolution of the Northern Lusitanian basin (Western Iberian margin). Basin Res 15:227-250

Alves TM, Moita C, Sandnes F, Cunha T, MonteiroJH Pinheiro LM (2006) Mesozoic-Cenozoic evolution of North Atlantic continental-slope basins: the Peniche basin, western Iberian margin. AAPG Bull 90:31-60

Alves TM, Moita C, Cunha T, Ullnaess M, Myklebust R, Monteiro JH, Manuppella G (2009) Diachronous evolution of Late Jurassic-Cretaceous continental rifting in the northeast Atlantic (west Iberian margin). Tectonics 28(TC4003):2008T. doi:10.1029/ C002337

Apalategui O, Eguíluz L, Quesada C (1990) Ossa-Morena zone: structure. In: Dallmeyer RD, Martínez-García E (eds) Pre-mesozoic geology of Iberia. Springer, Berlin, pp 280-292

Arenas R, Sánchez Martínez S, Gerdes A, Albert R, Díez Fernández $\mathrm{R}$, Andonaegui P (2013) Reinterpreting the Devonian ophiolites involved in the Variscan suture: $\mathrm{U}-\mathrm{Pb}$ and $\mathrm{Lu}-\mathrm{Hf}$ zircon data of the Moeche Ophiolite (Cabo Ortegal Complex, NW Iberia). Int J Earth Sci 103:1385-1402

Barbosa B, Ferreira Soares A, Rocha RB, Manuppella G, Henriques M (1988) Carta Geológica de Portugal, escala 1:50.000, Notícia explicativa da folha $\mathrm{n}^{\circ} 19 \mathrm{~A}$ - Cantanhede. Serviços Geológicos de Portugal, Lisboa, p 46

Barroso-Barcenilla F, Callapez PM, Ferreira Soares A, Segura M (2011) Cephalopod associations and depositional sequences from the upper Cenomanian and lower Turonian of the Iberian Peninsula (Spain and Portugal). J Iber Geol 37:9-28
Berthou PY (1984a) Albian-Turonian stage boundaries and subdivisions in the Western Portuguese Basin, with special emphasis on the Cenomanian-Turonian boundary in the Ammonite Facies and Rudist Facies. Bull Geol Soc Den 33:41-45

Berthou PY (1984b) Résumé synthétique de la stratigraphie et de la paléogéographie du Crétacé moyen et supérieur du bassin occidental portugais. Geonovas 7:99-120

Black LP, Kamo SL, Allen CM, Aleinikoff JA, Davis DW, Korsch RJ, Foudoulis C (2003) TEMORA 1: a new zircon standard for Phanerozoic U-Pb geochronology. Chem Geol 200:155-170

Boillot G, Froitzheim N (2001) Non-volcanic rifted margins, continental break-up and the onset of sea-floor spreading: Some outstanding questions, in Non-volcanic Continental Margins: A Comparison of Evidence From Land and Sea. In: Wilson RCL et al. (eds) Geol Soc Spec Publ 187:9-30

Callapez PM (2008) Palaeobiogeographic evolution and marine faunas of the Mid-Cretaceous Western Portuguese Carbonate Platform. Thalassas 24:29-52

Capdevila R, Mougenot D (1988) Pre-Mesozoic basement of the western Iberian continental margin and its place in the Variscan Belt. In: Mazzullo E K (ed) Proceedings of the Ocean Drilling Program, Scientific Results, Texas: Texas A \& M University, Ocean Drilling Program, College Station 103:3-12

Chichorro M, Pereira MF, Díaz-Azpiroz M, Williams IS, Férnandez C, Pin C, Silva JB (2008) Cambrian ensialic rift-related magmatism in the Ossa-Morena Zone (Évora-Aracena metamorphic belt, SW Iberian Massif): $\mathrm{Sm}-\mathrm{Nd}$ isotopes and SHRIMP zircon U-Th- $\mathrm{Pb}$ geochronology. Tectonophysics 461:91-113

Clarke DB, MacDonald MA, Tate MC (1997) Late Devonian maficfelsic magmatism in the Meguma zone, Nova Scotia. Geol Soc Am Mem 191:107-127

Crowley QG, Floyd PA, Winchester JA, Franke W, Holland JG (2000) Early Palaeozoic rift-related magmatism in Variscan Europe: fragmentation of the Armorican Terrane Assemblage. Terra Nova $12: 171-180$

Cunha PP, Reis RP (1995) Cretaceous sedimentary and tectonic evolution of the northern sector of the Lusitanian basin (Portugal). Cretac Res 16:155-170

Dallmeyer RD, Ribeiro A, Marques F (1991) Polyphase Variscan emplacement of exotic terranes (Morais and Bragança Massifs) onto Iberian successions: evidence from ${ }^{40} \mathrm{Ar} /{ }^{39} \mathrm{Ar}$ mineral ages. Lithos 27:133-144

Dercourt J, Gaetani M, Vrielynck B, Barrier E, Biju-Duval B, Brunet MF, Cadet JP, Crasquin S, Sandulescu M (eds) (2000) Atlas peri-tethys paleoegeographical maps. CCGM/CGMW, Paris

Dias G, Leterrier J, Mendes A, Simões PP, Bertrand JM (1998) U-Pb zircon and monazite geochronology of post-collisional Hercynian granitoids from the Central Iberian Zone (northern Portugal). Lithos 45:349-369

Díez Fernández R, Martínez Catalán JR, Gerdes A, Abati J, Arenas R, Fernández-Suárez J (2010) Age constraints on Lower Paleozoic convection system: magmatic events in the northwest Iberian Gondwana margin. Gondwana Res 18:385-399

Díez Fernández R, Castiñeiras P, Gómez Barreiro J (2012) Age constraints on Lower Paleozoic convection system: magmatic events in the northwest Iberian Gondwana margin. Gondwana Res 21:1066-1079

Díez Montes A, Martínez Catalánb JR, Bellido Mulas F (2010) Role of the Ollo de Sapo massive felsic volcanism of NW Iberia in the Early Ordovician dynamics of northern Gondwana. Gondwana Res 17:363-376

Dinis JL (2001) Definição da Formação da Figueira da Foz - Aptiano a Cenomaniano do sector central da margem oeste ibérica. Comunicações do Instituto Geológico e Mineiro 88:127-160 
Dinis JL, Trincão P (1995) Recognition and stratigraphical significance of the Aptian unconformity in the Lusitanian basin, Portugal. Cretac Res 16:171-186

Dinis JL, Rey J, Graciansky PC (2002) Le Bassin Lusitanien (Portugal) à l'Aptien supérieur-Albien: organisation séquentielle, proposition de corrélations, évolution. Compte Rendu Geoscience 334:757-764

Dinis JL, Rey J, Cunha PP, Callapez P, Reis RP (2008) Stratigraphy and allogenic controls of the western Portugal Cretaceous: an updated synthesis. Cretac Res 29:772-780

Dunning GR, Barr SM, Giles PSD, McGregor C, Pe-Piper G, Piper DJW (2002) Chronology of Devonian to early Carboniferous rifting and igneous activity in southern Magdalen Basin based on U-Pb (zircon) dating. Can J Earth Sci 39:1219-1237

Eguíluz L, Gil Ibarguchi JI, Abalos B, Apraiz A (2000) Superposed Hercynian and Cadomian orogenic cycles in the Ossa-Morena zone and related areas of the Iberian Massif. Geol Soc Am Bull 112:1398-1413

Fernández-Suárez J, Dunning GR, Jenner GA, Gutiérrez-Alonso G (2000) Variscan collisional magmatism and deformation in NW Iberia: constraints from $\mathrm{U}-\mathrm{Pb}$ geochronology of granitoids. $\mathrm{J}$ Geol Soc 157:565-576

Fernández-Suárez J, Gutiérrez-Alonso G, Cox R, Jenner GA (2002) Assembly of the Armorica microplate: a strike-slip terrane delivery? Evidence from $\mathrm{U}-\mathrm{Pb}$ ages of detrital zircons. J Geol 10:619-626

Fernández-Suárez J, Gutiérrez-Alonso G, Pastor-Galán D, Hoffman M, Murphy JB, Linnemann U (2013) The Ediacaran-Early Cambrian detrital zircon record of NW Iberia: possible sources and paleogeographic constraints. Int J Earth Sci. doi:10.1007/ s00531-013-0923-3

Galindo C, Casquet C (2004) El magmatismo prevarisco de la Zona de Ossa-Morena. In: Vera JA (ed) Geología de España. Sociedad Geológica de España-Instituto Geológico Minero España, Madrid, pp 190-194

Gardien V, Paquette JL (2004) Ion microprobe and ID-TIMS U-Pb dating on zircon grains from leg 173 amphibolites: evidence for Permian magmatism on the West Iberian margin. Terra Nova 16:226-231

Gradstein FM, Ogg JG, Smith AG (eds) (2004) A geological time scale 2004. Cambridge University Press, Cambridge

Gutiérrez-Alonso G, Fernández-Suárez J, Weil AB (2004) Orocline triggered lithospheric delamination. In: Weil AB, Sussman A (eds) Paleomagnetic and structural analysis of orogenic curvature, special paper. Geological Society of America, Boulder, pp 121-131

Gutiérrez-Alonso G, Fernández-Suárez J, Jeffries TE, Johnston ST, Pastor-Galán D, Murphy JB, Franco MP, Gonzalo JC (2011) Diachronous post-orogenic magmatism within a developing orocline in Iberia, European Variscides. Tectonics 30:1-17, TC5008. doi:10.1029/2010TC002845

Hart MB, Callapez PM, Fisher JK, Hannant K, Monteiro JF, Price GD, Watkinson MP (2005) Micropalaeontology and stratigraphy of the Cenomanian/Turonian boundary in the Lusitanian basin, Portugal. Journal of Iberian Geology 31:311-326

Hieptas J, Samson S, Moecher D, Chakraborty S (2011) Enhancing tectonic and provenance information from detrital zircon studies: assessing terrane-scale sampling and grain-scale characterization. J Geol Soc 168:309-318

Hiscott RN, Wilson R, Gradstein FM, Pujalte V, García-Mondéjar J, Boudreau RR, Wishart HA (1990) Comparative stratigraphy and subsidence history of Mesozoic rift basins of North Atlantic. AAPG Bull Tulsa 74(1):60-76

Hiscott RN, Marsaglia KM, Wilson RL, Robertson AHF, Karner GD, Tucholke BE, Pletsch T, Petschick R (2008) Detrital sources and sediment delivery to the early postrift (Albian-Cenomanian)
Newfoundland Basin east of the Grand Banks: results from ODP Leg 210. Bull Can Pet Geol 56:69-92. doi:10.2113/ gscpgbull.56.2.69

Jackson SE, Pearson NJ, Griffin WL, Belousova EA (2004) The application of laser ablation-inductively coupled plasma-mass spectrometry to in situ $\mathrm{U}-\mathrm{Pb}$ zircon geochronology. Chem Geol 211:47-69

Jacquin T, Rusciadelli G, Amedro F, Graciansky PC, Magniez-Jannin F (1998) The North Atlantic Cycle: an overview of 2nd-order transgressive/regressive cycle in the Lower Cretaceous of Western Europe. In: De Graciansky PC, Farley MB, Jacquin T, Vail PR (eds) Mesozoic and cenozoic sequence stratigraphy of European basins, 60. Society of Economic Paleontologists and Mineralogists Special Publication 397-409

Jagoutz O, Muntener O, Manatschal G, Rubatto D, Peron-Pinvidic G, Turrin BD, Villa IM (2007) The rift-to-drift transition in the North Atlantic: a stuttering start of the MORB machine? Geology 35:1087-1090

Jesus A, Munhá J, Mateus A, Tassinari C, Nutman A (2007) The Beja layered gabbroic sequence (Ossa-Morena Zone, Southern Portugal): geochronology and geodynamic implications. Geodin Acta 20:139-157

Koralay OE, Satir M, Dora OO (2001) Geochemical and geochronological evidence for Early Triassic calc-alkaline magmatism in the Menderes Massif, western Turkey. Int J Earth Sci 89:822-835

Lawrence RL, Cox R, Mapes RW, Coleman DS (2011) Hydrodynamic fractionation of zircon age populations. Geol Soc Am Bull 123:295-305

Leinfelder RR, Wilson RCL (1998) Third-order sequences in an Upper Jurassic rift-related second-order sequence, central Lusitanian basin, Portugal. In: Graciansky PC, Hardenbol J, Jacquin T, Vail PR (eds) Mesozoic and cenozoic sequence stratigraphy of European basins, SEPM Spec Pub 60:507-525

Liesa M, Carreras J, Castiñeiras P, Casas JM, Navidad M, Vilà M (2011) U-Pb zircon age of Ordovician magmatism in the Albera Massif (Eastern Pyrenees). Geol Acta 9:93-101

Linnemann U, Pereira MF, Jeffries T, Drost K, Gerdes A (2008) Cadomian Orogeny and the opening of the Rheic Ocean: new insights in the diachrony of geotectonic processes constrained by LA-ICP-MS U-Pb zircon dating (Ossa-Morena and SaxoThuringian Zones, Iberian and Bohemian Massifs). Tectonophysics 461:21-43

Lotze F (1945) Zur Gliederung der Varisziden der Iberischen Meseta. Geotekton Forsch 6:78-92

Lowe DG, Sylvester PJ, Enachescu ME (2011) Provenance and paleodrainage patterns of Upper Jurassic and Lower Cretaceous synrift sandstones in the Flemish Pass Basin, offshore Newfoundland, east coast of Canada. AAPG Bull 95:1295-1320

Ludwig KR (2008) Isoplot/Ex 3.70 a geochronological toolkit for Microsoft Excel. Berkeley Geochronology Center Special Publication No. 4

Marques FO, Ribeiro A, Munhá JM (1996) Geodynamic evolution of the Continental Allochthonous Terrane (CAT) of the Bragança Nappe Complex, NE Portugal. Tectonics 15:747-762

Martínez Catalán JR, Fernández-Suárez J, Jenner GA, Belousova E, Díez Montes A (2004) Provenance constraints from detrital zircon UPb ages in the NW Iberian Massif: implications for Paleozoic plate configuration and Variscan evolution. J Geol Soc Lond 161:461-473

Martínez Catalán JR, Arenas R, Díaz García F, González Cuadra P, Gómez-Barreiro J, Abati J, Castiñeiras P, Fernández-Suárez J, Sánchez Martínez S, Andonaegui P, González Clavijo E, Díez Montes A, Rubio Pascual FJ, Valle Aguado B (2007) Space and time in the tectonic evolution of the northwestern Iberian Massif: Implications for the Variscan belt. In: Hatcher Jr. 
RD, Carlson MP, McBride JH, Martínez Catalán JR (eds) 4-D Framework of Continental Crust. Geological Society of America Memoir 200:403-423

Martínez Catalán JR, Fernández-Suárez J, Meireles C, Clavijo EG, Belousova E, Saeed A (2008) U-Pb detrital zircon ages in synorogenic deposits of the NW Iberian Massif, Variscan belt: interplay of Devonian-Carboniferous sedimentation and thrust tectonics. J Geol Soc London 165:697-698

Miranda R, Valadares V, Terrinha P, Mata J, Azevedo MR, Gaspar M, Kullberg JC, Ribeiro C (2009) Age constraints on the Late Cretaceous alkaline magmatism on the West Iberian Margin. Cretac Res 30:575-586

Moecher DP, Samson SD (2006) Differential zircon fertility of source terranes and natural bias in the detrital zircon record: implications for sedimentary provenance analysis. Earth Planet Sci Lett 247:252-266

Moran PC, Barr SM, White CE, Hamilton MA (2007) Petrology, age, and tectonic setting of the Seal Island Pluton, offshore southwestern Nova Scotia. Can J Earth Sci 44:1467-1478

Murphy JB, van Staal CR, Collins WJ (2011) A comparison of the evolution of arc complexes in Paleozoic interior and peripheral orogens: speculations on geodynamic correlations. Gondwana Res 19(3):812-827

Nance RD, Murphy JB, Santosh M (2014) The supercontinent cycle: a retrospective essay. Gondwana Res 25:4-29

Orejana D, Villaseca C, Billstrom K, Paterson BA (2008) Petrogenesis of Permian alkaline lamprophyres and diabases from the Spanish Central System and their geodynamic context within western Europe. Contrib Miner Petrol 156:457-500

Pastor-Galán D, Gutiérrez-Alonso G, Murphy JB, Fernández-Suárez J, Hofmann M, Linnemann U (2013) Provenance analysis of the Paleozoic sequences of the northern Gondwana margin in NW Iberia: passive margin to Variscan collision and orocline development. Gondwana Res 23(3):1089-1103

Pearce NJG, Perkins WT, Westgate JA, Gorton MP, Jackson SE, Neal CR, Chenery SP (1997) A compilation of new and published major and trace element data for NIST SRM 610 and NIST SRM 612 glass reference materials. Geostand Newslett 21:115-144

Pe-Piper G, Triantafyllidis S, Piper DJW (2008) Geochemical identification of clastic sediment provenance from known sources of similar geology: the Cretaceous Scotian basin. Canada J Sed Res 78:595-607

Pereira MF, Silva JB, Drost K, Chichorro M, Apraiz A (2010) Relative timing of transcurrent displacements in northern Gondwana: U-Pb laser ablation ICP-MS and monazite geochronology of gneisses and sheared granites from the western Iberian Massif (Portugal). Gondwana Res 17:461-481

Pereira MF, Chichorro M, Solá AR, Silva JB, Sánchez-García T, Bellido F (2011) Tracing the Cadomian magmatism with detrital/ inherited zircon ages by in situ U-Pb SHRIMP geochronology (Ossa-Morena Zone, SW Iberian Massif). Lithos 123:204-217

Pereira MF, Chichorro M, Johnston ST, Gutiérrez-Alonso G, Silva JB, Linnemann U, Hofmann M, Drost K (2012a) The missing Rheic Ocean magmatic arcs: provenance analysis of Late Paleozoic sedimentary clastic rocks of SW Iberia. Gondwana Res 3-4:882-891

Pereira MF, Linnemann U, Hofmann M, Chichorro M, Solá AR, Medina J, Silva JB (2012b) The provenance of Late Ediacaran and Early Ordovician siliciclastic rocks in the Southwest Central Iberian Zone: constraints from detrital zircon data on northern Gondwana margin evolution during the late Neoproterozoic. Precambr Res 192-195:166-189

Pereira MF, Ribeiro C, Vilallonga F, Chichorro M, Drost K, Silva JB, Albardeiro L, Hofmann M, Linnemann U (2013) Variability over time in the sources of South Portuguese Zone turbidites: evidence of denudation of different crustal blocks during the assembly of Pangaea. Int J Earth Sci. doi:10.1007/ s00531-013-0902-8

Pereira MF, Castro A, Fernández C (2014) The inception of a Paleotethyan magmatic arc in Iberia. Geosci Front. doi:10.1016/j. gsf.2014.02.006

Pinheiro L, Wilson R, Reis RP, Whitmarsh R, Ribeiro A (1996) The western Iberia margin: a geophysical and geological overview. Proc Ocean Drill Program Sci Res 149:3-23

Pinto MS, Casquet C, Ibarrola E, Corretgé LS, Ferreira MP (1987) Síntese geocronológica dos granitóides do Maciço Hespérico. In: Bea F et al (eds) Geologia de los Granitoides y Rocas Associadas del Macizo Hespérico: Libro Homenaje a L. C. Garcia de Figuerola, Rueda, Madrid, pp 69-86

Piper DJW, Pe-Piper G, Hundert T, Venugopal D (2007) The lower Cretaceous Chaswood formation in southern New Brunswick: provenance and tectonics. Can J Earth Sci 44:665-677

Piper DJW, Pe-Piper G, Tubrett M, Triantafyllidis S, Strathdee G (2012) Detrital zircon geochronology and polycyclic sediment sources, Upper Jurassic-Lower Cretaceous of the Scotian Basin, southeastern Canada. Can J Earth Sci 49:1540-1557

Poller U, Uher P, Broska I, Plasienka D, Janák M (2002) First Permian-Early Triassic zircon ages for tin-bearing granites from the Gemeric unit (Western Carpathians, Slovakia): connection to the post-collisional extension of the Variscan orogen and S-type granite magmatism. Terra Nova 14:41-48

Puga E, Fanning M, Díaz de Federico A, Nieto JM, Beccaluva L, Bianchini G, Puga MAD (2011) Petrology, geochemistry and $\mathrm{U}-\mathrm{Pb}$ geochronology of the Betic Ophiolites: inferences for Pangaea break-up and birth of the westernmost Tethys Ocean. Lithos 124:255-272

Reis RP, Cunha PP, Dinis JL, Trincão PR (2000) Geologic evolution of the Lusitanian basin (Portugal) during the Late Jurassic. In: Hall RL, Smith PL (eds) Proceedings 5th international symposium on the Jurassic system. GeoResearch Forum 6:345-356

Rey J (1992) Les unités lithostratigraphiques du Crétacé inférieur de la région de Lisbonne. Comunicações dos Serviços Geológicos de Portugal 78:103-124

Rey J (1993) Les unités lithostratigraphiques du Grupe de Torres Vedras (Estremadura, Portugal). Comunicações do Instituto Geológico e Mineiro 79:75-85

Rey J (2006) Stratigraphie sequentielle et séquences de dépôt dans le Crétacé inférieur du Bassin Lusitanien. Ciências Terra, $\mathrm{n}^{\circ}$ esp VI

Rey J, Graciansky PC, Jacquin T (2003) Les séquences de dépôt dans le Crétacé inférieur du Bassin Lusitanien. Comunicações do Instituto Geológico e Mineiro 90:15-42

Rey J, Dinis JL, Callapez PM, Cunha PP (2006) Da rotura continental à margem passiva. Composição e evolução do Cretácico de Portugal. Cadernos de Geologia de Portugal. INETI, Lisboa

Reynolds PH, Pe-Piper G, Piper DJW (2010) Sediment sources and dispersion as revealed by single grain ${ }^{40} \mathrm{Ar} /{ }^{39} \mathrm{Ar}$ ages of detrital muscovite from Carboniferous and Cretaceous rocks in mainland Nova Scotia. Can J Earth Sci 47:957-970

Ribeiro A, Pereira E, Dias R (1990) Allochthonous sequences-structure in the northwest of the Iberian Peninsula. In: Dallmeyer RD, Martínez García E (eds) Pre-Mesozoic geology of Iberia. Springer, Berlin, pp 222-236

Ribeiro A, Munhá J, Dias R, Mateus A, Pereira E, Ribeiro L, Fonseca P, Araújo A, Oliveira T, Romão J, Chaminé H, Coke C, Pedro J (2007) Geodynamic evolution of the SW Europe Variscides. Tectonics 26(TC6009):2007. doi:10.1029/2006TC002058,170

Rosa DRN, Finch AA, Andersen T, Inverno CMC (2009) U-Pb geochronology and $\mathrm{Hf}$ isotope ratios of magmatic zircons from the Iberian Pyrite Belt. Mineral Petrol 95:47-69

Sahabi M, Aslanian D, Olivet J-L (2004) Un nouveau point de départ pour l'histoire de l'Atlantique central. C. R. Geoscience 336:1041-1052 
Schärer U, Girardeau J, Cornen G, Boillot G (2000) 138-121 Ma asthenospheric magmatism prior to continental break-up in the North Atlantic and geodynamic implications. Earth Planet Sci Lett 181:555-572

Segura M, Barroso-Barcenilla F, Callapez PM, García-Hidalgo J, Gil $\mathrm{J}$ (2014) Depositional sequences and ammonoid assemblages in the upper Cenomanian-lower Santonian of the Iberian Peninsula (Spain and Portugal). Geologica Acta 12(1):19-27

Shaw J, Gutiérrez-Alonso G, Johnston ST, Pastor Galán D (2014) Provenance variability along the Early Ordovician north Gondwana margin: paleogeographic and tectonic implications of $\mathrm{U}-\mathrm{Pb}$ detrital zircon ages from the Armorican Quartzite of the Iberian Variscan belt. Geol Soc Am Bull. doi:10.1130/B30935.1

Sibuet J-C, Rouzo S, Srivastava S (2012) Plate tectonic reconstructions and paleogeographic maps of the central and North Atlantic oceans. Revue canadienne des sciences de la Terre 49:1395-1415

Simancas JF, Tahiri A, Azor A, González Lodeiro F, Martínez Poyatos DJ, El Hadi H (2005) The tectonic frame of the VariscanAlleghanian orogen in Southern Europe and Northern Africa. Tectonophysics 398:181-198

Sláma J, Kosler J, Condon DJ, Crowley JL, Gerdes A et al (2008) Plezovice zircon A new natural reference material for $\mathrm{U}-\mathrm{Pb}$ and Hf isotopic microanalysis. Chem Geol 249:1-35. doi:10.1016/j. chemgeo.2007.11.005

Soares AF (1980) A «Formação Carbonatada» na região do BaixoMondego. Comunicações dos Serviços Geológicos de Portugal 66:99-109

Solá AR, Pereira MF, Williams IS, Ribeiro ML, Neiva AMR, Montero $\mathrm{P}$, Bea F, Zinger T (2008) New insights from U-Pb zircon dating of Early Ordovician magmatism on the northern Gondwana margin: the Urra Formation (SW Iberian Massif, Portugal). Tectonophysics 461:114-129

Stapel G, Cloetingh S, Pronkb B (1996) Quantitative subsidence analysis of the Mesozoic evolution of the Lusitanian basin (western Iberian margin). Tectonophysics 266:493-507

Talavera C, Montero P, Martínez Poyatos D, Williams H (2012) Ediacaran to Lower Ordovician age for rocks ascribed to the Schist Graywacke Complex (Iberian Massif, Spain): evidence from detrital zircon SHRIMP U-Pb geochronology. Gondwana Res 22:928-942

Talavera C, Montero P, Bea F, González Lodeiro F, Whitehouse M (2013) U-Pb Zircon geochronology of the Cambro-Ordovician metagranites and metavolcanic rocks of Central NW Iberia. Int J Earth Sci 120:1-23

Tankard AJ, Welsink HJ (1987) Extensional tectonics and stratigraphy of Hibernia oil field, Grand Banks, Newfoundland. AAPG Bull $71: 1210-1232$

Trabucho Alexandre J, Van Gilst RI, Rodríguez-López JP, Boer PL (2011) The sedimentary expression of oceanic anoxic event $1 \mathrm{~b}$ in the North Atlantic. Sedimentology 58:1217-1246

Tsikouras B, Pe-Piper G, Piper DJW, Schaffer M (2011) Varietal heavy mineral analysis of sediment provenance, Lower Cretaceous Scotian Basin, eastern Canada. Sed Geol 237:150-165
Tucholke BE, Sibuet J-C (2007) Leg 210 synthesis: tectonic, magmatic, and sedimentary evolution of the Newfoundland-Iberia rift. Proc Ocean Drill Program Sci Results 210:1-56

Tucholke BE, Sawyer DS, Sibuet J-C (2007) Breakup of the Newfoundland-Iberia rift. In: Karner GD, Manatschal G, Pinheiro LM (eds) Imaging, mapping and modelling continental lithosphere extension and breakup. Geological Society Special Publication 282:9-46

Valle Aguado B, Azevedo MR, Schaltegger U, Catalán JR, Nolan J (2005) U-Pb zircon and monazite geochronology of Variscan magmatism related to syn convergence extension in Central Northern Portugal. Lithos 82:169-184

Valverde-Vaquero P, Dunning GR (2000) New U-Pb ages for Early Ordovician magmatism in central Spain. J Geol Soc Lond 157:15-26

van Staal CR, Whalen JB, Valverde-Vaquero P, Zagorevski A, Rogers N (2009) Pre-Carboniferous, episodic accretion-related, orogenesis along the Laurentian margin of the northern Appalachians. In: Murphy JB, Keppie JD, Hynes AJ (eds) Ancient Orogens and Modern Analogues. Geological Society of London Special Publication 327:271-316

Vermeesch P (2004) How many grains are needed for a provenance study? Earth Planet Sci Lett 224:441-451

Vermeesch P (2012) On the visualisation of detrital age distributions. Chem Geol 312-313:190-194

Vermeesch P (2013) Multi-sample comparison of detrital age distributions. Chem Geol 341:140-146. doi:10.1016/j. chemgeo.2013.01.010

Whitmarsh RB, Wallace PJ (2001) The rift-to-drift development of the west Iberia nonvolcanic continental margin: a summary and review of the contribution of Ocean Drilling program Leg 173. In: Beslier M-O, Whitmarsh RB, Wallace PJ, Girardeau J (eds) Proceedings of the Ocean Drilling Project, Scientific Results 173:1-36

Whitmarsh RB, Miles PR, Sibuet J-C, Louvel V (1996) Geological and geophysical implications of deep-tow magnetometer observations near sites $897,898,899,900$ and 901 on the west Iberia continental margin. In: Whitmarsh RB, Sawyer DS, Klaus A, Masson DG. (eds) Proceedings of the Ocean Drilling Project, Scientific Results 149:665-674

Wiedenbeck M, Hanchar JM, Peck WH, Sylvester P, Valley J, Whitehouse $M$ et al (2004) Further characterisation of the 91500 zircon crystal. Geostand Geoanal Res 28:9-39

Wilson RCL (1979) A reconnaissance study of Upper Jurassic sediments of the Lusitanian basin. Ciências da Terra 5:53-84

Wilson RCL, Hiscott R, Willis M, Gradstein F (1989) The Lusitanian Basin of west central Portugal; Mesozoic and Tertiary tectonic, stratigraphic and subsidence history. In: Tankard, A. \& Balkwill, H., Extensional tectonics and stratigraphy of the North Atlantic margins. AAPG Memoir 46: 341-361 